\title{
LA PENSIÓN DE JUBILACIÓN TRAS LA REFORMA DE 2013
}

\author{
Iván Antonio Rodríguez CARDO \\ Profesor Titular de Derecho del Trabajo \\ y de la Seguridad Social \\ Facultad de Derecho \\ de la Universidad de Oviedo \\ rodriguezivan@uniovi.es
}

\begin{abstract}
RESUMEN
Las dudas sobre la viabilidad futura del sistema de pensiones y las consecuencias de la crisis económica ban acelerado una reforma estructural en la configuración de la pensión de jubilación. El endurecimiento de los requisitos de acceso a las distintas modalidades y las novedosas reglas de cálculo de cuantía y de compatibilidad con el trabajo requieren de un análisis que ponga de manifiesto posibles incoherencias o dificultades interpretativas. Parece claro, no obstante, que la reforma 2011-2013 dista de ser definitiva, pese a los largos periodos transitorios introducidos. Esa reforma ha de considerarse, seguramente, como el punto de partida de un largo proceso de ajuste, que se intensificará cuando las circunstancias económicas lo requieran.
\end{abstract}

Palabras clave: jubilación, Seguridad Social, factor de sostenibilidad, jubilación parcial, jubilación anticipada, compatibilidad.

\section{ABSTRACT}

Uncertainty about the future viability of the retirement pension system and the consequences of the economic crisis have boosted a significant change in the mapping of retirement pensions. Reinforcement of requirements to bave access to all different types and brand new rules to calculate its amount and compatibility with the working life brings the need for an analysis that makes likely inconsistencies or interpretation difficulties quite clear. However, it seems clear that the 20112013 reform is far from definite, in spite of the long temporary periods of time introduced. Such reform must be possibly considered as the starting point of a long adjustment process that will be reinforced when the economic needs require it.

Keywords: Retirement, Social Security, Sustainability Factor, Partial Retirement, Early Retirement, Compatibility.

\section{ZUSAMMENFASSUNG}

Die Zweifel an der zukünftigen Durchfübrbarkeit des Rentensystems und die Auswirkungen der Wirtschaftskrise haben die Ausgestaltung der Strukturreform der 
Renten beschleunigt. Die Zugangskritierien zu den verschiedenen Rentenmodalitäten, die strenger wurden sowie die neuen Berechnungsregeln der Rentenböhe und die Vereinbarkeit mit gewerblicher Arbeit machen eine Untersuchung notwendig, welche die möglichen Widersprüche und Auslegungsschwierigkeiten aufzeigt. Es scheint andererseits klar zu sein, dass die Rentenreform zwischen 2011 und 2013 weit davon entfernt ist, endgültig zu sein, auch wenn sie lange Übergangszeiten vorsiebt. Diese Rentenreform darf sicher als Ausgangspunkt eines langen Anpassungsprozesses verstanden werden, der sich intensivieren wird, sobald es die wirtschaftlichen Bedingungen erforderlich machen.

Schlüsselwörter: Rente, Sozialversicherung, Nachhaltigkeitsfaktor, Teilrente, Frührente, Vereinbarkeit.

SUMARIO: I. INTRODUCCIÓN.-II. RAZONES PARA LA REFORMA DEL SISTEMA DE PENSIONES: FACTORES ESTRUCTURALES Y COYUNTURALES.-III. LA NUEVA CONFIGURACIÓN DE LA JUBILACIÓN ORDINARIA.-1. Edad.—2. Período de carencia.—3. Base reguladora.-4. Porcentaje.IV. JUBILACIÓN ANTICIPADA POR CESE INVOLUNTARIO.-1. Dilemas del legislador y objetivos de la reforma.-2. Requisitos.-3. Cuantía.-V. JUBILACIÓN ANTICIPADA «POR VOLUNTAD DEL INTERESADO».-1. Requisitos.-2. Cuantía.-VI. JUBILACIÓN PARCIAL.-1. Objetivos de la reforma.-2. Requisitos de acceso.-VII. COMPATIBILIDAD ENTRE LA PENSIÓN DE JUBILACIÓN Y EL TRABAJO.--VIII. SUPUESTOS DE CONGELACIÓN DEL RÉGIMEN JURÍDICO.-IX. LA IMPLEMENTACIÓN DEL FACTOR DE SOSTENIBILIDAD.-X. CONSIDERACIONES FINALES.

\section{INTRODUCCIÓN}

La sostenibilidad de los sistemas de pensiones ha ocupado, y preocupado, a los países del llamado primer mundo desde hace décadas. El desarrollo de los Estados del Bienestar, y con ello de la Seguridad Social, que es un pilar esencial, exige incrementar el gasto público en prestaciones sociales. Las distintas coyunturas socioeconómicas hacen difícil en ocasiones encontrar equilibrios adecuados, porque un gasto social desorbitado repercute negativamente en el progreso económico, mientras que un gasto social reducido es incompatible con el carácter «social» que se predica del concreto Estado, según muchos textos constitucionales ${ }^{1}$. Ese imprescindible equilibrio entre lo social y lo económico exige una vigilancia constante de la evolución de los sistemas de Seguridad Social, pero en sí mismo no genera riesgos de viabilidad, más allá de los que pudieran derivarse de

${ }^{1}$ J. L. Tortuero PlazA, «Actualización del sistema de Seguridad Social (III): la reforma de la jubilación», Aranzadi Social, vol. 4, núm. 8 (2011), pp. 11-41. 
malas decisiones políticas. El riesgo real nace a partir de factores externos que motivan cambios no deseados, pero imprescindibles con el propósito de adaptarse a nuevas circunstancias.

Sin duda, el progresivo envejecimiento de la población exige una actuación en el ámbito de la Seguridad Social, actuación que se podría demorar - a costa de la progresividad en la aplicación-, pero que resulta indispensable si se pretenden mantener los rasgos que hacen identificable al sistema. Esa actuación puede incidir en distintos ámbitos, ya que podría afectar al campo de aplicación, a la gestión, a la cotización o a la extensión e intensidad de la acción protectora, de forma que las opciones son múltiples y en modo alguno excluyentes entre sí.

Ahora bien, la pensión de jubilación es uno de los ámbitos que sufrirá naturalmente las consecuencias de esta clase de reformas, ya que se trata de la prestación central y la que, en definitiva, genera un mayor coste para el erario público. No resulta extraño, así pues, que la Ley 27/2011 y el Real Decreto-ley 5/2013 hayan puesto el acento, precisamente, en las distintas modalidades de la pensión de jubilación, endureciendo los requisitos y aplicando fórmulas de cálculo que, en términos generales, provocan una reducción de la cuantía.

La pensión de jubilación, así pues, ha sufrido modificaciones notables que afectan a la jubilación ordinaria (edad, base reguladora o porcentaje), a la jubilación anticipada (con nuevas submodalidades y requisitos) y a la jubilación parcial (con unas exigencias mucho más rigurosas). Además, se ha establecido un nuevo régimen de compatibilidad entre la pensión de jubilación y el trabajo que supone una novedad muy relevante en relación con el contexto previo, y se contemplan como medidas transitorias determinadas excepciones a la entrada en vigor de esas normas que en la práctica permiten la congelación del régimen jurídico hasta 2019 para determinadas personas que tienen derecho a la aplicación de la legislación previa. Todo ello da lugar a un panorama de elevada complejidad que hace imprescindible la sistematización y un análisis pausado y exhaustivo.

\section{LA NECESIDAD DE UNA REFORMA DEL SISTEMA DE PENSIONES: FACTORES ESTRUCTURALES Y COYUNTURALES}

Como se sabe, la reforma del sistema de pensiones de 2011-2013 vino motivada por dos tipos de factores: estructurales y coyunturales. Los fac- 
tores estructurales pueden asimismo derivar de causas diversas, ya que se vinculan con elementos que afectan a los sistemas de pensiones a largo plazo y que, desde cierta perspectiva, son irremediables. En los países del primer mundo esos factores estructurales se relacionan con la demografía, mientras que en Estados en vías de desarrollo tienen más que ver con la aspiración de mejora socioeconómica y las expectativas de progreso de la sociedad. Por su parte, los factores coyunturales se conectan con circunstancias que dan lugar a dificultades concretas a corto plazo y generan problemas de liquidez o infraprotección puntual. No obstante, una vez superadas dichas dificultades los mecanismos de protección social pueden seguir operando del mismo modo y con el mismo nivel de intensidad precedente.

En verdad, tanto los factores estructurales como los coyunturales pueden llegar a afectar, de manera similar, a sistemas de Seguridad Social que se han creado y organizado a partir de modelos muy distintos. A modo de ejemplo, las dudas sobre la sostenibilidad del sistema de pensiones en un futuro próximo se han planteado tanto en los sistemas de los países nórdicos, de inspiración universalista o beveridgeano, como en los sistemas del resto de la Europa continental, de carácter contributivo o bismarckiano ${ }^{2}$. Las razones son simples: sean cuales sean el ámbito subjetivo y la intensidad de la acción protectora, los sistemas de pensiones establecen sus fuentes de obtención de ingresos en función de estimaciones de gasto. Cuando ese equilibrio se rompe porque el gasto se incrementa resulta imprescindible actuar y, o bien se reduce el gasto, o bien aumentan los ingresos. El factor demográfico afecta tanto a los modelos universalistas como a los contributivos, lo que justifica que sea necesario buscar soluciones en todos ellos.

En efecto, los Estados del llamado primer mundo comparten determinadas características demográficas que repercuten negativamente en los sistemas de pensiones. En particular, la tradicional representación gráfica de la estructura social como una pirámide ha quedado obsoleta, porque desde la década de los ochenta del pasado siglo la tasa de natalidad se redujo drásticamente en comparación, fundamentalmente, con el baby boom de los años sesenta. El acceso a la jubilación de esa generación del baby boom (a partir aproximadamente del 2025) incrementará notablemente el gasto social, que deberá ser soportado por las generaciones siguientes, mucho menos nutri-

2 A. H. BöRsCh-Supan y M. Miegel, Pension Reform in six countries. What can we learn from each other, Berlin, Springer, 2001, pp. 18 y ss. 
das. A ello se añade, sin duda, el aumento de la esperanza de vida, que obliga al pago de la prestación durante más tiempo 3 .

Conviene recordar que la edad de jubilación se ha fijado entre cincuenta y ocho y sesenta y cinco años en todos los países de Europa desde el mismo momento en que se creó la pensión de jubilación. En España, por ejemplo, el Retiro Obrero de 1919 situó esa edad en sesenta y cinco años, lo que contrastaba con la esperanza de vida, escasamente superior a cuarenta años, debido a las confrontaciones sociales, a las penosas condiciones de vida y trabajo, y al estado de la medicina, incapaz de hacer frente a muchas enfermedades y plagas, o de reducir sustancialmente la mortalidad infantil.

Casi un siglo después la edad de jubilación no había variado, pese al distinto contexto socioeconómico, y ello provoca, como señala la UE en el «Libro Blanco 2012: Ayuda para unas pensiones adecuadas, seguras y sostenibles», que «aproximadamente un tercio de la vida adulta transcurre en la jubilación, y si las políticas no cambian esta proporción se incrementaría en consonancia con los futuros aumentos de la esperanza de vida» (p. 7 $)^{4}$, lo que hace necesario implementar políticas dirigidas a vincular la edad de jubilación con los aumentos de la esperanza de vida. Con ello se justifica la introducción de medidas amparadas en el llamado «factor de sostenibilidad».

Los problemas estructurales del sistema de pensiones exigen cambios para adecuar los ingresos a la previsión de gasto. Pero esas dificultades no son inminentes, sino que comenzarán a apreciarse dentro de diez o quince años. Las reformas actuales de los sistemas de pensiones se justifican, en primer término, por motivos de conveniencia, ya que las resistencias de la población ante cambios que evidentemente perjudican expectativas de derechos se vencen más fácilmente a través de modificaciones con carácter progresivo.

No obstante, la urgencia de alguna de esas reformas y contrarreformas se explica, asimismo, por factores claramente coyunturales, pero que han acelerado la puesta en marcha de medidas estructurales. Esos factores coyunturales tienen relación con la situación económica mundial, y de España en particular, a partir de 2008. Desde luego, el mayor índice de desempleo repercute en el sistema de Seguridad Social, porque reduce los

3 B. SuÁrez Corujo, El sistema público de pensiones: crisis, reforma y sostenibilidad, Cizur Menor, Thomson-Reuters, 2014, pp. 67 y ss.

${ }^{4}$ Véase http://eur-lex.europa.eu/LexUriServ/LexUriServ.do?uri=COM:2012:0055:FIN. ES:PDF. 
ingresos por cotizaciones y con ello se generan problemas de liquidez puntuales en el pago de las prestaciones. Esa situación, por sí misma, no justifica la insistencia en una reforma estructural del sistema de pensiones, pues una vez que se supere la situación coyuntural la viabilidad estaría asegurada hasta más allá de 2025.

En verdad, las mayores restricciones en materia de jubilación introducidas en 2011-2013 se vinculan a la llamada «crisis de deuda». La deuda pública española a largo plazo no era bien apreciada por la incertidumbre que generaba la solvencia futura del Estado español si había de hacer frente a obligaciones en materia de pensiones que eran, a juicio de los potenciales inversores, inasumibles a medio plazo. La reforma del sistema de pensiones tendría como finalidad, precisamente, generar confianza para facilitar dichas inversiones.

Desde luego, también influyen sobre la reforma de las pensiones otros elementos coyunturales que requieren de actuaciones cuya puesta en práctica puede resultar perjudicial para la viabilidad del sistema público de Seguridad Social. En particular, se aprecian tensiones evidentes entre las medidas de política de empleo y la sostenibilidad de la Seguridad Social. En materia de política de empleo se justifican sin dificultad medidas de reducción o bonificación de cotizaciones, bien por colectivos o bien incluso con carácter general, con el fin de minorar las cargas para los empresarios y facilitar la contratación. Además, la pensión de jubilación ha sido utilizada también como instrumento de la política de empleo a través de sus distintas modalidades, y principalmente la jubilación parcial y la anticipada. Sin embargo, desde la perspectiva de la viabilidad del sistema de pensiones la reducción de las cotizaciones y la anticipación de la edad de jubilación causan un grave quebranto, de modo que resultaría aconsejable incrementar la cotización y restringir, o incluso suprimir, las jubilaciones a edades inferiores a la ordinaria. Las tensiones entre la política de empleo y la sostenibilidad del sistema son, así pues, manifiestas, y dan lugar a limitaciones recíprocas para conciliar los distintos intereses en juego.

En este escenario, el legislador ha debido afrontar una reforma estructural del sistema de pensiones, antes incluso de lo que habría deseado, por los efectos de la crisis económica. Los cambios exceden del ajuste técnico que ha caracterizado a las reformas en materia de Seguridad Social que se han sucedido desde la década de los setenta del pasado siglo con los eufemísticos propósitos de «consolidar», «racionalizar» o «perfeccionar» el sistema. La Ley 27/2011 prefiere otros eufemismos («actualización, ade- 
cuación y modernización»), pero no esconde que el objetivo que se persigue es más ambicioso que los que motivaron reformas precedentes, ya que no está en juego solamente atender a una dificultad puntual, sino dotar de mecanismos al sistema para que pueda resistir las consecuencias que el envejecimiento de la población provocará en un futuro cercano.

La necesidad de hacer frente a esa situación resulta incuestionable. Lo discutible, sin duda, son los remedios que pueden adoptarse. En último término, el legislador debe afrontar un desfase entre ingresos y gastos producto de un incremento - previsible - de los gastos en el futuro. Resulta imprescindible acomodar ingresos y gastos, y a tal fin cabe apostar por el incremento de ingresos, por la reducción de gastos, o bien por una combinación de ambos tipos de medidas. La Ley 27/2011 y con mayor intensidad el Real Decreto-ley 5/2013 (que puso fin a la suspensión aplicativa en materia de jubilación anticipada y parcial decidida por el Real Decreto-ley 29/2012) y la Ley 23/2013, de 23 de diciembre, han preferido centrarse en la contención del gasto, quizá porque no cabe calcular con la debida precisión cuál será la diferencia entre ingresos y gastos dentro de quince años, y porque cuanto menor sea esa diferencia en el futuro más fácil será tomar medidas de aumento de ingresos, tan impopulares como las de reducción de las prestaciones de Seguridad Social.

\section{LA NUEVA CONFIGURACIÓN DE LA JUBILACIÓN ORDINARIA}

Una de las novedades más sobresalientes de la Ley 27/2011 fue el aumento gradual de la edad ordinaria de jubilación, que se elevará paulatinamente desde los sesenta y cinco años iniciales a los sesenta y siete años en 2027. El período de carencia mantuvo su misma configuración, pero el método de cálculo de la base reguladora y del porcentaje aplicable en función de los años de cotización también sufrió variación.

\section{Edad}

La elevación de la edad de jubilación es, obviamente, la medida más simbólica dirigida a garantizar la viabilidad del sistema de Seguridad Social. En cierto modo, la jubilación a los sesenta y cinco años forma parte de la más arraigada tradición en España y las resistencias al cambio 
debían ser notables. Seguramente por ello, el legislador decidió no romper completamente con esa edad, manteniéndola como referencia, por ejemplo, en materia de jubilación anticipada histórica (DT 3. ${ }^{a}$ LGSS) o para el acceso a la pensión no contributiva de jubilación (art. 167 LGSS). En el mismo sentido, pese a la elevación de la edad de jubilación se contempla una excepción que permite causar pensión de jubilación a los sesenta y cinco años cuando el interesado acredite un período de cotización cualificado, establecido en treinta y ocho años y seis meses. Nótese que ese tiempo de cotización es superior al que se exigirá para disfrutar del 100 por 100 de la base reguladora (treinta y siete años). Y es posible la jubilación ordinaria — por más que el legislador haya preferido una ubicación incorrecta entre las modalidades de jubilación anticipada- a edades inferiores gracias a los coeficientes reductores de edad por el desempeño de trabajos penosos, tóxicos, insalubres, peligrosos o realizados por discapacitados.

Desde luego, la elevación de la edad de jubilación debe conectarse con la nueva configuración del mercado de trabajo y con el contexto socioeconómico y educativo (acceso al trabajo a edades tardías por necesidad de concluir estudios, generalización del contrato a tiempo parcial entre jóvenes, etc.). Como quiera que la acreditación de tan largos períodos de cotización a los sesenta y cinco años no será usual, en la generalidad de los casos no habrá una alternativa real para el interesado, que sólo podrá acceder a la jubilación ordinaria tras el cumplimiento de la nueva edad de jubilación situada en sesenta y siete años. El cómputo, según precisa el art. 1 del RD 1716/2012, debe efectuarse de fecha a fecha; cuando tal fecha no exista en el año concreto ( 29 de febrero) se toma como cumplimiento de la edad el último día del mes.

Como es habitual en esta clase de reformas, el endurecimiento de los requisitos de acceso se produce de manera gradual ${ }^{5}$, contemplándose un período transitorio hasta 2027, momento en el que, en principio, tendrá lugar la implantación plena de la reforma, aunque no cabe descartar una aceleración, que ya ha sido sugerida por el Banco de España y desde instancias de la UE. No obstante, en tanto no se tome una decisión de ese calibre, la elevación paulatina de la edad de jubilación se producirá del siguiente modo (DT 20. ${ }^{a}$ LGSS):

5 J. L. TORTUero Plaza, «La pensión de jubilación en el proyecto de ley "sobre actualización, adecuación y modernización”: aspectos básicos», Aranzadi Social, vol. 4, núm. 5 (2011), pp. 187-201. 


\begin{tabular}{|c|c|c|}
\hline$A \tilde{n} o$ & Períodos cotizados & Edad exigida \\
\hline \multirow{2}{*}{2013} & 35 años y 3 meses o más. & 65 años. \\
\hline & Menos de 35 años y 3 meses. & 65 años y 1 mes. \\
\hline \multirow{2}{*}{2014} & 35 años y 6 meses o más. & 65 años. \\
\hline & Menos de 35 años y 6 meses. & 65 años y 2 meses. \\
\hline \multirow{2}{*}{2015} & 35 años y 9 meses o más. & 65 años. \\
\hline & Menos de 35 años y 9 meses. & 65 años y 3 meses. \\
\hline \multirow{2}{*}{2016} & 36 o más años. & 65 años. \\
\hline & Menos de 36 años. & 65 años y 4 meses. \\
\hline \multirow{2}{*}{2017} & 36 años y 3 meses o más. & 65 años. \\
\hline & Menos de 36 años y 3 meses. & 65 años y 5 meses. \\
\hline \multirow{2}{*}{2018} & 36 años y 6 meses o más. & 65 años. \\
\hline & Menos de 36 años y 6 meses. & 65 años y 6 meses. \\
\hline \multirow{2}{*}{2019} & 36 años y 9 meses o más. & 65 años. \\
\hline & Menos de 36 años y 9 meses. & 65 años y 8 meses. \\
\hline \multirow{2}{*}{2020} & 37 o más años. & 65 años. \\
\hline & Menos de 37 años. & 65 años y 10 meses. \\
\hline \multirow{2}{*}{2021} & 37 años y 3 meses o más. & 65 años. \\
\hline & Menos de 37 años y 3 meses. & 66 años. \\
\hline \multirow{2}{*}{2022} & 37 años y 6 meses o más. & 65 años. \\
\hline & Menos de 37 años y 6 meses. & 66 años y 2 meses. \\
\hline \multirow{2}{*}{2023} & 37 años y 9 meses o más. & 65 años. \\
\hline & Menos de 37 años y 9 meses. & 66 años y 4 meses. \\
\hline \multirow{2}{*}{2024} & 38 o más años. & 65 años. \\
\hline & Menos de 38 años. & 66 años y 6 meses. \\
\hline \multirow{2}{*}{2025} & 38 años y 3 meses o más. & 65 años. \\
\hline & Menos de 38 años y 3 meses. & 66 años y 8 meses. \\
\hline \multirow{2}{*}{2026} & 38 años y 3 meses o más. & 65 años. \\
\hline & Menos de 38 años y 3 meses. & 66 años y 10 meses. \\
\hline \multirow{2}{*}{2027 y ss. } & 38 años y 6 meses o más. & 65 años. \\
\hline & Menos de 38 años y 6 meses. & 67 años. \\
\hline
\end{tabular}

\section{Período de carencia}

En la nueva configuración de la pensión de jubilación ordinaria el período mínimo de carencia genérico — no hay novedad alguna respecto de la carencia específica- dependerá de la edad a la que se pretenda acceder a la pensión. Desde luego, se mantiene el período mínimo de 
carencia genérica en quince años, pero ese tiempo de cotización únicamente permitirá causar pensión a la nueva edad de jubilación de sesenta y siete años o la que corresponda durante el período transitorio. Sin embargo, como se ha dicho, la jubilación desde los sesenta y cinco años sigue siendo posible para aquellos que acrediten un período de carencia cualificado, que a partir de 2027 se situará en treinta y ocho años y medio de cotización, sin la aplicación de días cuota, tras la Ley 40/2007 y el Real Decreto-ley 8/2010.

Cabe reseñar alguna novedad en relación con el modo de cálculo de esos períodos, toda vez que no sólo resulta imprescindible determinar el número de años de cotización a través de la fórmula tradicional (que consistía en dividir el número total de días entre 365), sino que la nueva regulación exige, asimismo, concretar el número de meses cotizados. A tal fin, el art. 1.2 del RD 1716/2012 precisa que el «mes adquiere el valor fijo de 30,41666 días», resultado de dividir por doce los 365 días que como valor fijo se asignan al año.

Aunque se trata de una cuestión no circunscrita específicamente a la jubilación, parece evidente que el modo de computar la cotización efectuada por los trabajadores a tiempo parcial cuenta con una gran trascendencia en materia de jubilación, como se puso de manifiesto en la STC 253/2004 y se volvió a reiterar en la STJUE, asunto C-385/11, de 22 de noviembre de 2012 (Elbal Moreno), y en la STC 61/2013, de 14 de marzo, que han declarado contraria a los principios de igualdad y no discriminación la fórmula de transformación de las horas trabajadas a tiempo parcial en días teóricos de cotización (número de horas cotizadas dividido por cinco y el resultado multiplicado por 1,5), por cuanto puede dar lugar a que personas con amplias carreras de seguro en tiempo natural queden excluidas de la pensión. Esas sentencias apuntan hacia una proporcionalidad en la cuantía de la pensión evitando endurecer el acceso.

La complejidad de la cuestión exigiría un análisis monográfico y desde luego excede del propósito del presente trabajo. Conviene señalar, no obstante, que quizá no fuera menester encontrar un criterio o procedimiento completamente diferente, porque únicamente se ha cuestionado la dificultad de alcanzar el período mínimo de carencia. En otras palabras, la conversión de horas de trabajo en días teóricos de cotización podría resultar aplicable en términos similares, pues no se ha probado que incurra en discriminación.

A los exclusivos efectos de evitar esa dificultad -y en la práctica imposibilidad - de causar pensión de jubilación en esos supuestos casi 
extremos no resulta suficiente la mejora del coeficiente multiplicador, novedad que se apuntaba en la DA 29. ${ }^{a}$ de la Ley 27/2011 — y que desde luego podría tener sentido para quienes sí cumplen los requisitos para acceder a la pensión-, porque ningún coeficiente multiplicador razonable permitiría alcanzar el período mínimo de carencia a personas como las demandantes en los supuestos de hecho litigiosos, ya que en algún caso la jornada rondaba el 10 por 100 en comparación con un trabajador a tiempo completo. Una opción plausible consistiría en generalizar la fórmula de cálculo del desempleo, de modo que cada día trabajado se equiparase a día cotizado, con independencia del número de horas. De esa forma se evitaría el problema señalado en las sentencias citadas, pero se generaría uno distinto, ya que la equivalencia día trabajado-día cotizado beneficia sin duda a los trabajadores a tiempo parcial horizontal, frente a los trabajadores a tiempo parcial vertical. La fórmula declarada inconstitucional era, sin duda, más homogénea e igualitaria. Una eventual solución podría consistir en computar como período de referencia el tiempo en el que el contrato haya estado vigente, con independencia de que el trabajador haya prestado o no servicios todos los días. También es posible elaborar un concepto ad hoc de trabajo a tiempo parcial en el sistema de Seguridad Social desligado del laboral o establecer tramos de cotización en función de horas trabajadas, como sucede, por ejemplo, en el Sistema Especial de Empleados del Hogar ${ }^{6}$.

Son fórmulas, en todo caso, que exigen cierta maduración y que requieren de la adopción de medidas analizadas cuidadosamente, porque la adecuada protección de los trabajadores no debe dar lugar a situaciones proclives al fraude. Aunque no parece viable suprimir los complementos a mínimos en estos casos - el principio de suficiencia de las prestaciones consagrado en el art. 41 CE se presenta como un obstáculo de notable envergadura-, quizá sí resulta adecuado establecer para esta clase de supuestos de trabajo a tiempo parcial con jornada prácticamente marginal un límite de cuantía ad hoc coincidente con el importe de las pensiones no contributivas, protección natural de quienes no hayan podido reunir un período de cotización suficiente, en extensión e intensidad, como para disfrutar de una pensión de jubilación contributiva «estándar».

\footnotetext{
${ }^{6}$ A. Llorente Áldarez y J. I. Del Valle de Joz, «La Seguridad Social de los trabajadores a tiempo parcial: jurisprudencia reciente y alternativas de reforma», Aranzadi Social, vol. 6, núm. 3 (2013), pp. 25-44.
} 
El legislador ha apostado finalmente por una opción compleja, diferenciando entre el período mínimo de carencia y la cuantía de la pensión. El art. 5 del Real Decreto-ley 11/2013, de 2 de agosto, para la protección de los trabajadores a tiempo parcial y otras medidas urgentes en el orden económico y social, y posteriormente la Ley 1/2014, de 28 de febrero, del mismo título, modificaron la DA 7. ${ }^{a}$ LGSS para introducir una nueva regulación en esta materia y crearon las figuras del «coeficiente de parcialidad» y del «coeficiente global de parcialidad». En primer término, el precepto exige tomar en consideración «los distintos períodos durante los cuales el trabajador haya permanecido en alta con un contrato a tiempo parcial, cualquiera que sea la duración de la jornada realizada en cada uno de ellos». Para cada período ha de calcularse el «coeficiente de parcialidad, que viene determinado por el porcentaje de la jornada realizada a tiempo parcial respecto de la jornada realizada por un trabajador a tiempo completo comparable». Conviene dejar constancia de que el precepto no concreta si las horas complementarias, y eventualmente las extraordinarias, cuentan con relevancia o si el único dato determinante, como así parece, es el porcentaje de jornada pactado en el contrato. No es descartable que esta cuestión genere problemas prácticos futuros. El coeficiente de parcialidad «se aplicará sobre el período de alta con contrato a tiempo parcial, siendo el resultado el número de días que se considerarán efectivamente cotizados en cada período». Lógicamente, al «número de días que resulten se le sumarán, en su caso, los días cotizados a tiempo completo, siendo el resultado el total de días de cotización acreditados computables para el acceso a las prestaciones» ${ }^{7}$.

A modo de ejemplo, si un trabajador acredita 1.000 días de cotización a tiempo completo y además ha prestado servicios durante 4.000 días a tiempo parcial con una jornada del 50 por 100 , el coeficiente de parcialidad será, precisamente, de un 50 por 100, que aplicado a los 4.000 días

7 J. LÓPEZ Gandía y D. TosCani GiméNEZ, La protección social de los trabajadores a tiempo parcial y fijos discontinuos, 2.. ${ }^{a}$ ed., Albacete, Bomarzo, 2014, pp. 22 y ss.; J. CABEZA PEREIRO, «Trabajo a tiempo parcial: reformas en materia laboral y de Seguridad Social», Actualidad Laboral, núm. 9 (2014), pp. 965 y ss.; Y. SÁNCHEZ-URÁn AZAÑA, «"Readaptación” del trabajo a tiempo parcial a los principios configuradores del sistema de Seguridad Social», Documentación Laboral, núm. 99 (2013), pp. 106 y ss.; J. F. LousadA ArochenA, «Protección social del trabajo a tiempo parcial según el RD-Ley 11/2013, de 2 de agosto», Aranzadi Social, vol. 6, núm. 7 (2013), pp. 95 y ss.; F. Fernández Prol, «Trabajadores a tiempo parcial, novedades en materia de cotización y reformulación de las reglas de cómputo de los períodos carenciales», Revista de Derecho Social, núm. 64 (2013), pp. 87 y ss., y F. ReQueJo GuTIÉRREZ, «Seguridad Social de los trabajadores a tiempo parcial tras el RD-Ley 11/2013, de 2 de agosto», Aranzadi Social, vol. 6, núm. 7 (2013), pp. 109 y ss. 
naturales de prestación de servicios ofrece un resultado de 2.000 días efectivos de cotización. Esos días han de sumarse a los cotizados a tiempo completo, lo que supone que el sujeto cuenta con 3.000 días totales de cotización.

Tras esta operación «se procederá a calcular el coeficiente global de parcialidad, siendo éste el porcentaje que representa el número de días trabajados y acreditados como cotizados [...] sobre el total de días en alta a lo largo de toda la vida laboral del trabajador», o bien sobre el período de referencia que corresponda para las distintas prestaciones, como sucede respecto de la IT (cinco años) o, dependiendo de la edad del beneficiario, del subsidio de maternidad, entre otras (paternidad o muerte y supervivencia). Ese coeficiente global de parcialidad debe aplicarse al período mínimo de cotización previsto para los trabajadores a tiempo completo, de modo que la exigencia se reduce en atención, precisamente, a la entidad de la jornada realizada a tiempo parcial.

En el caso anteriormente propuesto, el interesado acreditaba 3.000 días efectivos de cotización sobre un total de días en alta de 5.000. El coeficiente global de parcialidad asciende, pues, al 60 por 100, coeficiente que, aplicado al período mínimo de cotización para la pensión de jubilación (quince años), supone que el período mínimo de carencia se reduciría a nueve años de cotización (3.285 días), requisito que, en todo caso, se incumpliría en este supuesto.

En fin, conviene asimismo dejar constancia de la mejora de los períodos ficticios de cotización por cuidado de hijos tras la Ley 27/2011. Como se sabe, el art. 180 LGSS recoge prestaciones familiares de carácter no económico que se encuadran en la «modalidad contributiva» de tales prestaciones. En ese marco se computaban como cotizados los períodos de excedencia por cuidado de hijos o de otros familiares coincidentes con el tiempo de reserva de puesto de trabajo conforme a la legislación laboral, y se consideraban cotizados al 100 por 100 determinados períodos de reducción de jornada por cuidado de hijo. Además, la DA 44. ${ }^{a}$ LGSS obligaba a computar un mínimo de 112 días de cotización por cada hijo en relación trabajadoras que, por alguna razón, no hubieran cotizado la totalidad de las seis semanas posteriores al parto.

La Ley 27/2011, en primer lugar, aumentó a tres años el período de ocupación cotizada correspondiente a la excedencia por cuidado de hijos, lo que supone, en definitiva, computar como cotizado todo el tiempo en tal situación. Y, en segundo lugar, añadió una DA 60. ${ }^{a}$ a la LGSS con el fin de establecer un nuevo período de ocupación cotizada de hasta —en fun- 
ción de las interrupciones de cotización- 270 días en 2019 (con períodos transitorios hasta entonces, comenzando desde 112 días en $2013^{8}$, si bien se aplican hasta 270 días por cada hijo desde el 1 de enero de 2013 a los exclusivos efectos de determinar la edad mínima de acceso a la jubilación ordinaria y alcanzar, por tanto, el tiempo de cotización necesario para continuar causando la pensión a los sesenta y cinco años) con el propósito de cubrir eventuales lagunas de cotización por «extinción de la relación laboral»o «finalización del cobro de prestaciones de desempleo producidas entre los nueve meses anteriores al nacimiento o los tres meses anteriores a la adopción o acogimiento permanente y la finalización del sexto año posterior a dicha situación». La regulación más completa de este beneficio se encuentra en los arts. 5 a 9 del RD 1716/2012, pero entre sus rasgos principales destaca la limitación a los trabajadores asalariados, el posible disfrute por ambos progenitores, aunque con preferencia por la madre, y el límite total del período de ocupación cotizada a cinco años (de los seis potenciales de laguna), límite en el que no sólo se toma en consideración este beneficio de hasta 270 días por cada hijo, sino también otros de la misma naturaleza, y en particular el tiempo en excedencia por cuidado de hijos o menores acogidos.

El objetivo de este beneficio consiste, exclusivamente, en mejorar el importe de las prestaciones (todas, salvo desempleo) y no, por tanto, en dulcificar los requisitos de acceso, de modo que el beneficio no resulta de aplicación para cubrir períodos mínimos de carencia y tampoco este tiempo de cotización ficticia se considera como situación asimilada al alta para evitar que se puedan causar prestaciones ( $v$. gr., maternidad), tal y como por interpretación jurisprudencial se admitió durante la excedencia por cuidado de hijos?.

\begin{tabular}{|c|c|}
\hline Año & Días computables \\
\hline 2013 & 112 \\
\hline 2014 & 138 \\
\hline 2015 & 164 \\
\hline 2016 & 191 \\
\hline 2017 & 217 \\
\hline 2018 & 243 \\
\hline 2019 y ss. años & 270 \\
\hline
\end{tabular}

9 Véase STS de 15 de diciembre (rcud. 1071/2003). El art. 6 del RD 1335/2005 considera esta situación como «alta» y no alta asimilada. 


\section{Base reguladora}

La forma de cálculo de la base reguladora afecta a todas las modalidades de la pensión de jubilación y no exclusivamente a la jubilación ordinaria. No obstante, se ubica en este apartado por razones sistemáticas, al igual que ocurre con el porcentaje aplicable a la base reguladora. En ambos casos la reforma operada por la Ley 27/2011 se debe, en términos generales, a la intención del legislador de reducir globalmente el coste de las prestaciones, si bien en el concreto caso de la base reguladora las peculiaridades de la carrera de seguro de cada beneficiario serán determinantes. En este sentido, la extensión del período de referencia para el cálculo de la base reguladora, tomando eventualmente toda la vida laboral, no supone necesariamente un perjuicio para el trabajador, sino que puede beneficiar a personas que, por variadas circunstancias, sufren una reducción de las bases de cotización en los años inmediatamente anteriores al hecho causante de la pensión de jubilación. Es cierto, no obstante, que en carreras de seguro más clásicas, donde la retribución del trabajador aumenta con el tiempo gracias a su mayor experiencia y a la adquisición de nuevas responsabilidades, el cómputo de los años más próximos a la jubilación ofrece un mejor resultado para el interesado.

En la redacción original de la LGSS 1994 la base reguladora de la pensión de jubilación coincidía con la base reguladora de la IP por enfermedad común y se calculaba, por tanto, a partir de la media de las bases de cotización de los ocho años anteriores al hecho causante (96/112, siendo 96 el número de meses, y, por tanto, de bases de cotización en ese período, y 112 el número de pagas extraordinarias que teóricamente deberían haberse abonado, de modo que las pagas extraordinarias se prorratean en la base cotización, pero no afectan a la cuantía de la pensión). La Ley 24/1997 elevó el período de referencia a quince años (180/210) tras el oportuno período transitorio. La Ley 27/2011 da un nuevo paso hacia el cómputo de toda la vida laboral y establece como período a tomar en consideración veinticinco años (300/350), aunque esa ampliación también es objeto de una aplicación paulatina conforme a la siguiente escala (DT 5. ${ }^{a}$ LGSS):

\begin{tabular}{|c|c|}
\hline Año & Fórmula de cálculo \\
\hline 2013 & $192 / 224$ (16 años) \\
\hline 2014 & $204 / 238$ (17 años) \\
\hline 2015 & $216 / 252$ (18 años) \\
\hline
\end{tabular}




\begin{tabular}{|l|l|}
\hline Año & Fórmula de cálculo \\
\hline 2016 & $228 / 266$ (19 años) \\
\hline 2017 & $240 / 280(20$ años $)$ \\
\hline 2018 & $252 / 294(21$ años $)$ \\
\hline 2019 & $264 / 308(22$ años $)$ \\
\hline 2020 & $276 / 322(23$ años $)$ \\
\hline 2021 & $288 / 336(24$ años $)$ \\
\hline 2022 y ss. & $300 / 350(25$ años $)$ \\
\hline
\end{tabular}

En este período transitorio se introduce una regla adicional dirigida a beneficiar - no se aprecia ninguna contraindicación- a quienes hayan sufrido una disminución no deseada de su base de cotización en los años inmediatamente precedentes a la jubilación. En concreto, pueden acceder a esa ventaja los trabajadores que hayan visto extinguido involuntariamente su contrato a partir de los cincuenta años por una causa considerada como situación legal de desempleo, tomando como referencia la «relación laboral más extensa de su carrera de cotización extinguida después de cumplir los cincuenta años de edad» (art. 2 del RD 1716/2012), siempre que «a partir del cumplimiento de los cincuenta y cinco años de edad, y al menos durante veinticuatro meses, hayan experimentado una reducción de las bases de cotización respecto de la acreditada con anterioridad a la extinción de la relación laboral» ${ }^{10}$. Esos veinticuatro meses no deben ser necesariamente consecutivos y «han de estar comprendidos entre el cumplimiento de la edad de cincuenta y cinco años, o la de extinción de la relación laboral por causa no imputable a la libre voluntad del trabajador, si ésta es posterior al cumplimiento de dicha edad, y el mes anterior al mes previo al del hecho causante de la pensión de jubilación» ${ }^{11}$.

La pérdida del empleo, y como consecuencia la reducción de las bases de cotización, en un período cercano al acceso a la jubilación puede derivar en un notable quebranto en el importe de la pensión, máxime en situa-

${ }^{10}$ M. A. Castro Argüelles, «Actualización del sistema de Seguridad Social (III): la reforma de la jubilación», Aranzadi Social, vol. 4, núm. 8 (2011), pp. 11 y ss. En idéntico sentido véase colaboración de J. Hierro Hierro en el mismo estudio.

${ }^{11}$ «En el caso de trabajadores por cuenta propia o autónomos, con respecto a los cuales haya transcurrido un año desde la fecha en que se haya agotado la prestación por cese de actividad, la aplicación de lo establecido en los apartados 2 y 3 de la disposición transitoria quinta de la Ley General de la Seguridad Social queda condicionada a que dicho cese, producido a partir del cumplimiento de los cincuenta y cinco años de edad, lo haya sido respecto de la última actividad realizada previa al hecho causante de la pensión de jubilación» [art. 2.c) del RD 1716/2012]. 
ciones de crisis económica y financiera donde el número de empresas en dificultades aumenta y los trabajadores maduros se ven perjudicados en mayor medida que otros colectivos. En ese contexto, el legislador ofrece una opción —no una imposición — que demuestra que la extensión del período de referencia no siempre deriva en un resultado negativo. Es posible cuestionarse por qué esta medida se limita a ese concreto colectivo y no a cualesquiera personas afectadas por una reducción de bases de cotización en los momentos previos al hecho causante, pero su carácter benéfico resulta innegable.

Más concretamente, la base reguladora de la pensión de jubilación cuando el hecho causante se produzca hasta 31 de diciembre de 2016 será la que derive de las reglas transitorias transcritas, salvo que sea menor que la que resultaría de aplicar como fórmula de cálculo la prevista para 2017, es decir, la media de las bases de cotización de los últimos veinte años. Se produce, así pues, una aplicación anticipada de la fórmula de cálculo cuando beneficie al interesado. Similar operación debe efectuarse para las personas en las mismas condiciones cuando el hecho causante se produzca entre 1 de enero de 2017 y el final de 2021, ya que su base reguladora será la más elevada entre las dos opciones que siguen: la que correspondería en atención al período transitorio o la resultante de anticipar la completa entrada en vigor de la norma (300/350).

No obstante la aplicación paulatina y la introducción de este beneficio, la ampliación del período de referencia para el cálculo de la base reguladora puede suponer un perjuicio importante para los beneficiarios, toda vez que no se establecen reglas que modulen el cálculo en función de la extensión de la carrera de seguro del trabajador, a diferencia de lo que sucede en la IP por enfermedad común, por ejemplo. En efecto, el art. 140 LGSS contempla una fórmula de cálculo similar a la de la pensión de jubilación, tomando como referencia los últimos ochos años. Sin embargo, el apartado 2 deja claro que «en los supuestos en que se exija un período mínimo de cotización inferior a ocho años» deben computarse «bases mensuales de cotización en número igual al de meses de que conste el período mínimo exigible» para evitar un perjuicio desmedido para quienes cumplen el período mínimo de carencia, pero no han cotizado durante todo el período de referencia para la base reguladora.

El legislador ha prescindido de esa modulación en la pensión de jubilación. Con anterioridad a la reforma, el período mínimo de carencia se situaba en quince años, al igual que el período de cálculo de la base reguladora. Es evidente que el tiempo de cotización no debe ser acreditado en 
el momento inmediatamente anterior al hecho causante, porque la carencia específica se limita a dos años dentro de los últimos quince, pero esta admisión de posibles descubiertos de cotización no es obstáculo para considerar que, en hipótesis, el legislador permitía que un trabajador que reuniera el período mínimo de cotización no tuviera lagunas en el cálculo de su base reguladora, siempre que su cotización se concentrase en el tramo final de su vida laboral.

La Ley 27/2011 altera notablemente esa configuración, pues el período mínimo de carencia sigue situado en quince años, mientras que la base reguladora, tras los períodos transitorios, tomará como referencia veinticinco años, lo que sin duda hará frecuentes las lagunas de cotización. Los perjuicios para el beneficiario se agudizan con el nuevo régimen legal relativo, precisamente, a la integración de lagunas, porque la regla tradicional, que obligaba a integrar esos descubiertos con bases mínimas, ha sido sustituida por otra más rigurosa. La Ley 27/2011 introducía un complejo procedimiento ${ }^{12}$ no necesariamente en perjuicio del trabajador, sino que incluso podría resultar más beneficioso ${ }^{13}$. Esas reglas nunca entraron en vigor, al haber sido modificadas por la Ley 3/2012. Desde 1 de enero de 2013 el art. 162.1.2 LGSS dispone que «si en el período que haya de tomarse para el cálculo de la base reguladora aparecieran meses durante los cuales no hubiese existido obligación de cotizar, las primeras cuarenta y ocho mensualidades se integrarán con la base mínima de entre todas las existentes en cada momento y el resto de mensualidades con el 50 por 100 de dicha

12 «Si en el período que haya de tomarse para el cálculo de la base reguladora aparecieran períodos durante los cuales no hubiese existido la obligación de cotizar, dichas lagunas se integrarán de acuerdo con las siguientes reglas: $1 .{ }^{a}$ Si durante los treinta y seis meses previos al período que ha de tomarse para el cálculo de la base reguladora existieran mensualidades con cotizaciones, cada una de las correspondientes bases de cotización dará derecho, en su cuantía actualizada, a la integración de una mensualidad con laguna de cotización y hasta un máximo de veinticuatro, a partir de la mensualidad más cercana al hecho causante de la pensión, en los términos y condiciones que se establezcan reglamentariamente. En ningún caso la integración podrá ser inferior al 100 por 100 de la base mínima vigente en la fecha correspondiente a la mensualidad que es objeto de integración. 2." ${ }^{a}$ Las veinticuatro mensualidades con lagunas más próximas al período al que se refiere la regla anterior se integrarán con el 100 por 100 de la base mínima vigente en la fecha correspondiente a la mensualidad que es objeto de integración. 3.. ${ }^{a}$ El resto de mensualidades con lagunas de cotización se integrarán con el 50 por 100 de la base mínima vigente en la fecha correspondiente a la mensualidad que es objeto de integración».

${ }_{13}$ F. Cavas Martínez, «Actualización del sistema de Seguridad Social (III): la reforma de la jubilación», Aranzadi Social, vol. 4, núm. 8 (2011), pp. 11 y ss., y D. TosCAni Giménez, «La reforma de la jubilación a edad ordinaria por la Ley 27/2011», Aranzadi Social, vol. 4, núm. 7 (2011), pp. 149 y ss. 
base mínima». La referencia a las «primeras cuarenta y ocho mensualidades» no ha de ser entendida como los vacíos de cotización en los dos años inmediatamente precedentes al hecho causante, sino como cualesquiera meses sin cotización, consecutivos o no, durante el período de referencia, de modo que la regla de integración de lagunas más perjudicial sólo se aplicaría cuando en el período de cómputo hubiera más de cuarenta y ocho meses sin cotización.

Por consiguiente, en el nuevo contexto, y en función del número de meses sin cotización, el beneficiario se expone a un doble perjuicio, ya que a las eventuales lagunas producidas por el incremento del período de carencia se une el nuevo procedimiento de integración. Piénsese, por ejemplo, en una persona que reúna quince años de cotización y todos ellos inmediatamente anteriores al hecho causante; con la legislación precedente no se producirían lagunas en la base reguladora, mientras que tras la plena aplicación de la reforma no sólo sufriría las consecuencias de diez años de laguna, sino que la mayor parte de esas lagunas quedarían integradas con la mitad de la base mínima.

\section{Porcentaje}

La modificación relativa a la base reguladora, aunque globalmente beneficiosa para la viabilidad del sistema, no resulta perjudicial para el beneficiario en todo caso, a diferencia de la reforma operada en el porcentaje aplicable, que siempre arroja un resultado negativo en comparación con la normativa precedente, pues sea cual sea la situación del sujeto el porcentaje será inferior, salvo el aparejado al período mínimo de carencia, que permanece en un 50 por 100 .

Como se sabe, en el régimen jurídico precedente a la Ley 27/2011 el art. 163 LGSS permitía aumentar el porcentaje en un 3 por 100 por cada año adicional de cotización entre el quince y el veinticinco (momento en que correspondería un 80 por 100), y en un 2 por 100 por cada año adicional a partir del vigesimosexto. Recuérdese que el art. 9 de la Orden de 18 de enero de 1967 disponía que «para determinar el número de años de cotización que han de servir para fijar el porcentaje de la pensión se dividirá el total de los días cotizados por trescientos sesenta y cinco, y la fracción de años, si existiera, se asimilará a un año completo de cotización, cualquiera que sea el número de días que comprenda». 
La Ley 27/2011 modificó el art. 163 LGSS estableciendo un procedimiento mucho más complejo y que ya no utiliza como parámetro de referencia los años de cotización, sino los meses. El período mínimo de carencia de quince años sigue suponiendo un porcentaje del 50 por 100 de la base reguladora, pero ahora se añade que «por cada mes adicional de cotización, comprendidos entre los meses 1 y 248, se añadirá el 0,19 por 100 , y por los que rebasen el mes 248 , se añadirá el 0,18 por 100 , sin que el porcentaje aplicable a la base reguladora supere el 100 por 100». Esta regulación se prevé de aplicación plena en 2027 y supone una evidente reducción de la cuantía de la pensión final por comparación con la legislación previa ${ }^{14}$.

La conversión de los días de cotización en años y meses tiene lugar de la forma antes expuesta, de modo que al año se asigna un valor fijo de 365 días y al mes un valor fijo de 30,41666 días, pero sin redondeo al alza, a diferencia de la legislación anterior, porque no se equipará al año o al mes la fracción sobrante tras efectuar la pertinente división (art. 1.2 del RD 1716/2012). Por cierto, para la determinación de los días de cotización de los trabajadores a tiempo parcial la DA 7. ${ }^{a}$ LGSS, tras la modificación operada por el art. 5 de la Ley 1/2014, obliga a calcular, como ya se dijo, «el coeficiente de parcialidad, que viene determinado por el porcentaje de la jornada realizada a tiempo parcial respecto de la jornada realizada por un trabajador a tiempo completo comparable». Dicho coeficiente «se aplicará sobre el período de alta con contrato a tiempo parcial, siendo el resultado el número de días que se considerarán efectivamente cotizados en cada período». Ahora bien, a efectos de cuantía estos días de cotización se incrementarán «con la aplicación del coeficiente del 1,5, sin que el número de días resultante pueda ser superior al período de alta a tiempo parcial». En los supuestos en los que el interesado no alcance un mínimo de quince años de cotización, pero aún así pueda acceder a la pensión, el porcentaje será «el equivalente al que resulte de aplicar a 50 el porcentaje que represente el período de cotización acreditado por el trabajador sobre quince años». A modo de ejemplo, un trabajador que presta servicios durante veinte años con una jornada del 40 por 100, sin ninguna cotización distinta, tendrá un coeficiente de parcialidad del 40 por 100 y, por tanto, contará con ocho años efectivos de cotización, que se elevan a doce por aplicación del coeficiente de 1,5. Esos doce años equivalen al 80 por 100 de los quin-

${ }^{14}$ M. A. PÉREZ Alonso, «La nueva pensión de jubilación y otras reformas en el sistema de Seguridad Social», Aranzadi Doctrinal, núm. 6 (2012), pp. 147 y ss. 
ce años que se exigen como período de carencia genérica. Por consiguiente, el porcentaje aplicable a la base reguladora de este trabajador se situaría en el 80 por 100 de 50, esto es, un 40 por 100. La Ley 1/2014 no precisa si las reglas de concesión del complemento a mínimos resultarán idénticas para este colectivo, lo que obliga a consultar anualmente la Ley de Presupuestos para comprobar si se establece alguna peculiaridad.

$\mathrm{Al}$ margen de estas diferencias, conviene tener en cuenta que 248 meses equivalen a veinte años y ocho meses de cotización, de modo que el beneficiario que cuente con 248 meses de cotización adicionales a los primeros quince años acreditará treinta y cinco años y ocho meses de cotización. Conforme a la legislación precedente alcanzaría el 100 por 100 de la base reguladora. Tras la reforma, el porcentaje quedará reducido a un 95,6 por 100 para quienes acrediten treinta y cinco años exactos de cotización, y a un 97,12 por 100 con esos treinta y cinco años y ocho meses. Téngase en cuenta que, como se dijo, el porcentaje aplicable por cada año de cotización entre los quince y los veinticinco ascendía al 3 por 100, mientras que, tras la reforma, el porcentaje de 0,19 por 100 supone un 2,28 por 100 anual, que si bien es mayor que el 2 por 100 antes aplicable por cada año adicional de cotización a partir de los veinticinco, no es suficiente para compensar la diferencia. El objetivo de la nueva regulación es situar el porcentaje máximo del 100 por 100 en treinta y siete años de cotización, de modo que el incremento del 0,18 por 100 por cada mes adicional (un 2,16 por 100 anual) a partir del mes 248 resulta aplicable a los dieciséis meses siguientes, que son suficientes para alcanzar ese 100 por 100.

Esta nueva regulación entrará en vigor, como se dijo, en 2027. Hasta entonces se contemplan tres períodos transitorios menos rigurosos. El primero abarca desde 2013 a 2019, y aunque la dinámica de aplicación es similar, el propósito consiste en permitir que el 100 por 100 de la base reguladora sea alcanzado con treinta y cinco años y seis meses de cotización. A tal fin se prevé que por cada mes adicional —una vez reunidos quince años de cotización- entre el 1 y el 163 (esto es, trece años y siete meses, o, lo que es lo mismo, un total de veintiocho años y siete meses de cotización) se aplique un porcentaje del 0,21 por 100 (2,52 por 100 anual), porcentaje que se reduce al 0,19 por 100 a partir de ese mes durante los 83 meses que restarían hasta alcanzar los treinta y cinco años y medio de cotización, y con ello el 100 por 100. El porcentaje que correspondería a treinta y cinco años de cotización se sitúa en el 98,86 por 100 .

Entre 2020 y 2022 se podrá alcanzar el 100 por 100 de la base reguladora con treinta y seis años de cotización, y para ello se aplicará un por- 
centaje del 0,21 por 100 por cada mes adicional entre el 1 y el 106 (ocho años y diez meses, es decir, veintitrés años y diez meses totales de cotización). Por cada mes adicional al 106, y durante los siguientes 146 meses (doce años y dos meses), deberá aplicarse un porcentaje del 0,19 por 100 . Las personas con treinta y cinco años de cotización recibirán un 97,72 por 100 de la base reguladora.

Finalmente, entre 2023 y 2026 será necesario alcanzar treinta y seis años y seis meses de cotización para disfrutar del 100 por 100 de la base reguladora. Por cada mes adicional a partir del decimoquinto año se aplicará un porcentaje del 0,21 por 100 , siempre que estos meses se sitúen entre el mes 1 y el 49 (cuatro años y un mes), y por cada mes siguiente a partir del 49 (diecisiete años y cinco meses, 209 meses) un porcentaje del 0,19 por 100. Los beneficiarios con treinta y cinco años de cotización disfrutarán de un 96,58 por 100 de la base reguladora.

La reforma no sólo ha afectado al porcentaje ordinario aplicable a la base reguladora, sino también al porcentaje adicional por retraso de la edad de jubilación. Como se sabe, el art. 163.2 LGSS antes de la Ley $27 / 2011$ permitía incrementar la pensión en un 2 por 100 por cada año completo «transcurrido» desde el cumplimiento de la edad ordinaria de jubilación, porcentaje elevado «al 3 por 100 cuando el interesado hubiera acreditado al menos cuarenta años de cotización al cumplir sesenta y cinco años». Tras la reforma que entró en vigor el 1 de enero de 2013, el art. 163.2 LGSS alude a años completos «cotizados» de retraso de la jubilación para evitar las dudas interpretativas que había suscitado la referencia a «transcurridos», y que resolvió la jurisprudencia no sólo aludiendo a años cotizados, sino matizando que en caso de trabajo a tiempo parcial resultaba imprescindible efectuar la conversión de las horas trabajadas en días teóricos de cotización, y con ello un año natural de trabajo a tiempo parcial no permitía generar ese porcentaje adicional ${ }^{15}$.

Esa jurisprudencia parece plenamente compatible con la alusión a periodos «cotizados» tras la Ley 27/2011. Pero al margen de esa novedad, la reforma destaca por mejorar sustancialmente esos porcentajes adicionales con el fin de incentivar el retraso voluntario de la edad de jubilación. Como es sabido, el porcentaje adicional depende de los años de cotización acreditados en el momento del cumplimiento de la edad ordinaria de jubilación. El porcentaje será de un 2 por 100 por cada año completo de retraso siempre que el interesado acredite menos de veinticinco años de cotización; de

15 Véanse SSTS de 21 de marzo y de 15 de noviembre (rcud. 2396/2010 y 1765/2011). 
un 2,75 por 100 cuando reúna entre veinticinco y treinta y siete años cotizados, y de un 4 por 100 cuando en el momento de cumplir la edad ordinaria de jubilación alcance treinta y siete años de cotización. Nótese que ese tiempo de cotización, treinta y siete años, coincide con el que a partir de 2027 será necesario para percibir el 100 por 100 de la base reguladora. Habría resultado conveniente introducir períodos transitorios coincidentes con los ya expuestos para el porcentaje ordinario, de modo que este porcentaje adicional del 4 por 100 pudiera generarse por la continuidad en activo una vez que el interesado ya reúne los requisitos para disfrutar del 100 por 100 de la base reguladora. Cabe recordar que la DA 24. .a de la Ley 27/2011 ordena al gobierno la elaboración de un estudio actuarial al objeto de evaluar la adaptación de estos porcentajes adicionales a «los principios de proporcionalidad y contributividad al sistema» ${ }^{16}$.

\section{JUBILACIÓN ANTICIPADA POR CESE INVOLUNTARIO}

Pese a su denominación, esta modalidad no es accesible a partir de cualquier extinción involuntaria del contrato, sino que es una modalidad de jubilación anticipada vinculada directamente a situaciones de reestructuración empresarial ${ }^{17}$. Como novedad, el Real Decreto-ley 5/2013 ha ampliado las causas que permiten disfrutar de la pensión, ya que la previsión originaria de la Ley 27/2011 limitaba el concepto de cese involuntario a las extinciones derivadas de causas económicas, mientras que tras el Real Decreto-ley 5/2013 se mencionan asimismo las causas técnicas, organizativas y de producción.

\section{Dilemas del legislador y objetivos de la reforma}

Como ya se advirtió, las actuaciones legislativas en distintos campos propician tensiones evidentes, por cuanto determinadas medidas cuentan con efectos muy positivos para el mercado de trabajo, pero generan con-

${ }^{16}$ A. V. SEmpere NAVArRo, «Actualización del sistema de Seguridad Social (III): la reforma de la jubilación», Aranzadi Social, vol. 4, núm. 8 (2011), pp. 11 y ss.

${ }_{17}$ S. GonZÁlez Ortega, «La jubilación anticipada: valoración y posibles propuestas de reconfiguración de su régimen jurídico», Aranzadi Social, vol. 6, núm. 1 (2013), pp. 33 y ss., y L. LÓPez Cumbre, «Jubilaciones anticipadas en extinción», Documentación Laboral, núm. 99 (2013), pp. 81 y ss. 
traindicaciones evidentes para el sistema de Seguridad Social, y viceversa. Esas tensiones no solamente se manifiestan en relación con las políticas de empleo en sentido propio, tanto en su vertiente activa (reducciones, bonificaciones o exenciones de cuotas) como en la pasiva (intensidad de la acción protectora frente al desempleo), sino que alcanzan a la configuración del sistema de Seguridad Social y, en particular, de la pensión de jubilación, ya que el régimen jurídico de esa prestación ha sido puesto al servicio de la política de empleo frecuentemente.

$\mathrm{Al}$ margen de las medidas dirigidas al mantenimiento del empleo de las personas maduras [exoneración de cuotas más allá de la edad de jubilación con derecho al 100 por 100 de la base reguladora (art. 112 bis LGSS) o porcentaje adicional por retraso de la edad de jubilación], que tienen como propósito principal contribuir a la viabilidad del sistema, algunas modalidades de jubilación fueron creadas y configuradas con la firme intención de fomentar el empleo. Así sucedió especialmente con la jubilación parcial y la ya desaparecida jubilación especial a los sesenta y cuatro años. Además, la jubilación anticipada —amén de la denominada prejubilación, e incluso también la IP, a través de una notable flexibilidad en la valoración del estado psicofísico del interesado- ha sido utilizada también con ese propósito, pues mediante el adelanto de la jubilación se han favorecido procesos de reestructuración empresarial, principalmente en la década de los ochenta del pasado siglo.

Es claro que en la actualidad las jubilaciones anteriores a los sesenta y cinco años ponen en riesgo la sostenibilidad del sistema, porque el período de cotización se reduce y las obligaciones de pago a cargo del erario público se incrementan. No resulta extraño, por consiguiente, que el legislador haya optado por el endurecimiento paulatino de los requisitos de acceso a estas modalidades. Ahora bien, en un contexto caracterizado por el aumento de la edad de jubilación ordinaria y por la incertidumbre que genera el futuro del sistema de pensiones podría resultar extraño que estas modalidades sigan perviviendo. En un análisis exclusivamente económico, la supresión de la jubilación anticipada podría derivar, en último término, en un ahorro equivalente al que implica el aumento de la edad ordinaria de jubilación u otras medidas que contribuyan a la disminución de la cuantía de la pensión.

Sin embargo, el legislador ha preferido mantener la jubilación anticipada. Detrás de esa decisión se esconde un reconocimiento implícito del fracaso de las políticas activas de empleo para trabajadores maduros. El legislador es consciente de que la pérdida de empleo a edades próximas a 
la jubilación supone, frecuentemente, la exclusión del mercado de trabajo, sin posibilidades reales de reincorporarción a la vida activa. El trabajador, por consiguiente, se verá abocado a las prestaciones sociales, habitualmente a la de desempleo. La jubilación anticipada simplemente formaliza esa exclusión de facto del mercado de trabajo y clarifica que los esfuerzos de las políticas activas de empleo se dirigirán a personas con mejores posibilidades de reinserción laboral.

No obstante, el objetivo — declarado- de acercar la edad real de jubilación a la legal impide una configuración generosa de la jubilación anticipada. La reforma de 2011-2013 se mueve en esos parámetros, pues trata de conciliar el propósito de contribuir a la viabilidad del sistema con el positivo papel que en ocasiones despliega la jubilación anticipada como medida de fomento del empleo. En ese contexto, la modalidad general de jubilación anticipada - la histórica no se modifica por tratarse de una fórmula a extinguir en breve tiempo y con un ámbito de aplicación muy reducido- se subdivide en dos modalidades. La primera de ellas, con requisitos menos rigurosos, trata de facilitar procesos de restructuración empresarial y vincula la jubilación anticipada a esas situaciones de crisis empresarial. La segunda, en cambio, no atiende al motivo por el que el trabajador ha cesado en el trabajo, y quizá por ello los requisitos resultan notablemente más rigurosos y en modo alguno atractivos ${ }^{18}$.

Conviene poner de manifiesto, no obstante, que las denominaciones elegidas por el legislador son notablemente desafortunadas. La primera de esas modalidades recibe el nombre de jubilación anticipada derivada del «cese en el trabajo por causa no imputable al trabajador», mientras que la segunda se califica como jubilación anticipada por «voluntad del interesado». La denominación induce a confusión, pues en ambos casos la jubilación parte de la solicitud del propio interesado, de forma que, desde una perspectiva estrictamente jurídica —la compulsión económica no puede confundirse con la obligación jurídica-, ambas son modalidades de jubilación de carácter voluntario. Podría pensarse que esa voluntariedad se predica del cese en el trabajo, pero un análisis de los requisitos demuestra que esa primera impresión resulta equivocada. En efecto, la primera modalidad de jubilación anticipada no resulta accesible cualquiera que sea la forma de extinción del contrato y ni siquiera se remite al concepto de

18 J. GARCía MuRCiA, «Las nuevas reglas sobre jubilación parcial y jubilación anticipada: el RDL 5/2013. Un nuevo paso en la reforma legal de la jubilación», Derecho de los Negocios, núm. 269 (2013), pp. 62 y ss. 
situación legal de desempleo, sino que sólo encaja formas muy concretas de extinción. En consecuencia, la segunda de las modalidades está abierta a personas que cesan voluntariamente en el trabajo, pero también a personas que han sufrido un cese involuntario por una causa distinta de la prevista en esa otra modalidad.

\section{Requisitos}

En cierto modo la jubilación anticipada derivada del «cese en el trabajo por causa no imputable al trabajador» es, en apariencia, una adaptación de la modalidad general de jubilación anticipada previa a la reforma. Al menos algunos de sus requisitos se asemejan notablemente, como sucede con la edad, el período de inscripción como desempleado o la carencia genérica. La novedad, sin duda, se encuentra en las causas de cese en el trabajo.

Comenzando por la edad, con anterioridad a la reforma, la modalidad general de jubilación anticipada resultaba accesible desde los sesenta y un años, frente a los sesenta y cinco de la jubilación ordinaria. Tras la reforma de 2011-2013, la modalidad de jubilación anticipada por «cese involuntario» puede ser reconocida a quienes tengan «cumplida una edad que sea inferior en cuatro años, como máximo, a la edad» ordinaria de jubilación que en cada momento se establezca, sin posibilidad de dulcificación a través de coeficientes reductores de edad por trabajos penosos, peligrosos, tóxicos o insalubres. Es, pues, un requisito equivalente que parece conducir a una edad mínima de sesenta y tres años para el acceso a la jubilación anticipada. No obstante, ya se advirtió que la jubilación ordinaria a los sesenta y cinco años es posible si se reúne un período de cotización cualificado, de modo que aún se admite la jubilación anticipada a los sesenta y un años. En la medida en que en este punto no se contempla una excepción ni se permite computar ficticiamente como cotizado el tiempo que restaría para el cumplimiento de la edad ordinaria de jubilación, este período de carencia cualificado - treinta y ocho años y medio, o el que corresponda en los períodos transitorios- debe acreditarse en el momento del hecho causante de la pensión, lo que indudablemente dificultará el acceso a la jubilación anticipada a los sesenta y un años.

Se mantiene, asimismo, para esta modalidad otro de los requisitos exigidos para el disfrute de la jubilación anticipada general antes de la reforma, de modo que resulta imprescindible que el solicitante se encuentre inscrito como demandante de empleo «durante un plazo de, al menos, 
seis meses inmediatamente anteriores a la fecha de la solicitud de la jubilación». En cambio, se ha endurecido el período de carencia genérico, que en la modalidad general de jubilación anticipada se situaba en treinta años y que en la jubilación anticipada por cese involuntario se eleva hasta treinta y tres años, sin que se hayan establecido períodos transitorios, y por ello este nuevo requisito resulta aplicable desde 17 de marzo de 2013, fecha de entrada en vigor del Real Decreto-ley 5/2013.

Sin duda, la novedad más reseñable es la restrictiva definición de «cese involuntario», que impide considerar esta modalidad como una continuación natural de la jubilación anticipada general prevista con anterioridad. En efecto, la legislación anterior admitía como cese involuntario cualquier extinción del contrato que encajase entre las situaciones legales de desempleo contempladas en el art. 208 LGSS. Sin embargo, esta nueva modalidad sólo es accesible cuando se produzca una extinción contractual a resultas de una «situación de reestructuración empresarial que impida la continuidad de la relación laboral». Y esas situaciones se precisan en la propia norma:

1. El despido colectivo por causas económicas, técnicas, organizativas o de producción conforme al art. 51 del Estatuto de los Trabajadores. Conviene tener presente que la Ley 27/2011 había limitado las causas a las económicas, obviando el resto, que fueron añadidas por el Real Decreto-ley 5/2013.

2. El despido objetivo por causas económicas, técnicas, organizativas o de producción conforme al art. 52.c) del Estatuto de los Trabajadores. Al igual que sucedía con el despido colectivo, la redacción original de la Ley 27/2011 únicamente aludía a causas económicas. En cualquier caso, conviene poner de manifiesto que la extinción contractual por la vía de cualesquiera otras causas distintas previstas en el art. 52 ET no permite causar esta modalidad de jubilación anticipada.

3. La extinción del contrato por resolución judicial conforme al art. 64 de la Ley 22/2003, de 9 de julio, Concursal.

4. La muerte, jubilación o incapacidad del empresario individual, salvo que pueda aplicarse la normativa sobre transmisión de empresas, o la extinción de la personalidad jurídica del contratante.

5. La extinción del contrato de trabajo motivada por la existencia de fuerza mayor conforme al art. 51.7 ET.

6. La extinción de la relación laboral de la mujer trabajadora como consecuencia de ser víctima de la violencia de género. 
Por consiguiente, cualquier otra causa de extinción contractual no se considera cese involuntario a estos efectos, porque no encaja en el concepto de reestructuración empresarial. Resulta sorprendente la inclusión en este apartado de los ceses decididos por las víctimas de violencia de género, pues el supuesto no guarda identidad de razón con el resto. Claro está, se trata de una decisión basada en motivos de índole humanitaria, pero cabría preguntarse por qué ese colectivo constituye la única excepción.

Con objeto de evitar el fraude, el legislador precisa que en supuestos de despido colectivo o de despido objetivo del art. 52.c) ET, la solicitud de jubilación anticipada únicamente merecerá respuesta positiva si el solicitante prueba que ha percibido la indemnización correspondiente derivada de la extinción del contrato de trabajo o bien demuestra que ha interpuesto demanda judicial en «reclamación de dicha indemnización o de impugnación de la decisión extintiva». A tal efecto se precisa que «el percibo de la indemnización se acreditará mediante documento de la transferencia bancaria recibida o documentación acreditativa equivalente». La literalidad del precepto suscita dudas en relación con el pago en metálico, que seguramente no debiera admitirse ${ }^{19}$. No es una incertidumbre comparable con la consignación de la indemnización para evitar el devengo de los salarios de tramitación, pues en ese supuesto el propósito consiste en aumentar en lo posible la protección del trabajador. En cambio, esta acreditación del medio de pago en materia de jubilación anticipada trata de proteger al sistema de Seguridad Social y parte de una sospecha de fraude por parte del propio trabajador, en connivencia con el empresario, de modo que no es suficiente que el trabajador afirme haber recibido la indemnización. El legislador exige constancia documental y, preferiblemente, a través de un intermediario —entidad bancaria - que disipe cualquier duda sobre la intención de las partes ${ }^{20}$.

También podría cuestionarse la eficacia de los acuerdos alcanzados en conciliación previa, si bien la Administración considera «acreditado que el cese en el trabajo se produjo por causa ajena a la voluntad del trabajador si

${ }^{19}$ C. GonZÁLEZ GonZÁLeZ, «La reforma de la jubilación por el RD-Ley 5/2013, de 15 de marzo», Aranzadi Doctrinal, núm. 10 (2013), pp. 57 y ss.

${ }_{20}$ «Ha de rechazarse, en consecuencia, como prueba de haber cobrado la indemnización por despido colectivo u objetivo, cualquier título de crédito ejecutivo, como letras de cambio, pagarés o cheques; se aceptarán, en cambio, como prueba de dicho cobro, los ingresos en cuenta del beneficiario que respondan a la indemnización debida, los certificados bancarios del abono de títulos ejecutivos mercantiles o cualquier documento notarial que dé fe del pago de la indemnización». Cfr. criterio de aplicación 1/2014, de 10 de enero, de la Subdirección General de Ordenación y Asistencia Jurídica del INSS (BISS, enero de 2014). 
en la copia certificada del acta administrativa consta la extinción de la relación laboral por despido colectivo u objetivo debido a causas económicas, técnicas, organizativas o de producción, y el acuerdo indemnizatorio ajustado a la legalidad laboral» ${ }^{21}$.

El precepto no aclara si la calificación del despido es relevante y, por tanto, qué sucede en supuestos de improcedencia o nulidad. La improcedencia, además, puede ser declarada judicialmente, pero también reconocida por el propio empleador. Desde luego, de la voluntas legislatoris podría inferirse un deseo de regularidad en esta clase de decisiones, y de ahí la exigencia de demostración del percibo de la indemnización o, en su defecto, de impugnación judicial. Sin embargo, la ausencia de más precisión normativa obliga a considerar irrelevante la calificación del despido. La improcedencia reconocida por el propio empresario no es obstáculo para considerar que el trabajador ha sido objeto de un despido objetivo o colectivo, porque la modalidad depende de la causa alegada y la calificación opera en un plano distinto. En último término, el contrato se habría extinguido y el trabajador habría percibido la indemnización, que es, en esencia, lo que la norma exige ${ }^{22}$.

Más dudas pueden suscitarse en supuestos de readmisión, bien sea tras la declaración del despido nulo, bien sea tras la opción en tal sentido una vez calificada la extinción como improcedente. La readmisión implica formalmente que la relación laboral no se ha extinguido y obliga a devolver la pertinente indemnización. La readmisión debería provocar la extinción de la pensión de jubilación anticipada, con obligación de devolución de las prestaciones indebidas. El trabajador debería retornar a su puesto de trabajo, recibiendo los salarios de tramitación que correspondan.

No obstante, ésa es una situación compleja, pues la readmisión en estas situaciones de reestructuración empresarial podría incluso llegar a ser imposible o muy negativa para el trabajador. La declaración de nulidad o improcedencia podría demorarse años en caso de recursos procesales, y no conviene olvidar que la empresa que procedió al despido se encontraba en un contexto de dificultades evidentes, por lo que el retorno del trabajador resultará materialmente imposible. En la medida en que el legislador no ha previsto un procedimiento de comprobación a posteriori, sino exclusivamente en el momento de la solicitud, y no se concede relevancia expresa a la calificación del despido, parece irrelevante que en último tér-

\footnotetext{
${ }^{21}$ Ibid.

22 C. González GonZÁlEZ, «La reforma de la jubilación...», op. cit.
} 
mino la extinción se considere procedente, improcedente o nula, o que una vez reconocido el derecho a pensión se decida la readmisión. El derecho fundamental a la tutela judicial efectiva impide situar a un trabajador ante la disyuntiva de reclamar sus legítimos derechos laborales o percibir una pensión. El resultado de esa demanda no puede, por tanto, dar lugar a una privación de derechos. Cuestión distinta es que si el interesado decide reincorporarse a su puesto de trabajo deban aplicarse las reglas de compatibilidad pertinentes.

\section{Cuantía}

La jubilación anticipada tiene como peculiaridad que el beneficiario debe hacer frente a una penalización en la cuantía de la pensión por la «insolidaridad» que supone iniciar su disfrute antes de la edad ordinaria. El cálculo de la base reguladora y del porcentaje en función de los años y meses de cotización sigue el mismo procedimiento que en la jubilación ordinaria, pero una vez aplicado ese porcentaje a la base reguladora es menester introducir un coeficiente reductor de pensión que dependerá, por un lado, de la amplitud de la carrera de seguro del beneficiario y, por otro, del tiempo que reste hasta el cumplimiento de la jubilación ordinaria.

Como es sabido, con anterioridad a la Ley 27/2011 la penalización oscilaba entre un 6 y un 7,5 por 100 por cada año de anticipación, en atención a la cotización acreditada por el beneficiario en el momento del hecho causante. En concreto, el coeficiente más elevado (el 7,5 por 100) se reservaba para los beneficiarios que reunían una cotización de entre treinta y treinta y cuatro años inclusive; la penalización se situaba en el 7 por 100 por año de anticipación para quienes contaban con un período de cotización de entre treinta y cinco y treinta y siete años; en el 6,5 por 100 cuando la cotización se situaba entre treinta y ocho y treinta y nueve años, y en el 6 por 100 para beneficiarios con cuarenta o más años de cotización.

En su redacción original, la Ley 27/2011 procedió a una alteración de este procedimiento, pues el parámetro temporal de referencia para calcular el coeficiente ya no estaría basado en los años que restasen al interesado para reunir la edad ordinaria de jubilación, sino en los trimestres, y a ese efecto se establecían dos coeficientes reductores en función de la cotización $(1,875$ y 1,625 por 100 según el interesado acreditara o no treinta 
y ocho años y medio de cotización) ${ }^{23}$. Esa regulación nunca llegó a entrar en vigor al verse afectada por la suspensión aplicativa decidida por el Real Decreto-ley 29/2012. El Real Decreto-ley 5/2013, no obstante, partió de esa base, si bien retornó a cuatro coeficientes reductores.

En efecto, desde el 17 de marzo de 2013 la penalización se fija en 1,875 por 100 por trimestre o fracción que reste para el cumplimiento de la edad ordinaria (se computa ficticiamente como cotizado el tiempo que falta hasta ese momento para determinar la edad ordinaria de jubilación) cuando el beneficiario acredite menos de treinta y ocho años y medio de cotización; será de 1,750 por 100 cuando la cotización se sitúe entre treinta y ocho años y medio y cuarenta y un años y medio; de 1,625 por 100 para carreras de seguro entre cuarenta y un años y medio y cuarenta y cuatro años y medio, y de 1,500 por 100 para beneficiarios con cotización superior a cuarenta y cuatro años y medio. Conviene tener presente el art. 6 del RD 1716/2012, en el que se dispone que «los periodos computados como cotizados en concepto de beneficios por cuidado de hijos o menores acogidos se aplicarán a las jubilaciones anticipadas previstas en el art. 161 bis.1 de la Ley General de la Seguridad Social a todos los efectos, excepto para reducir la edad de jubilación que corresponda y para el cumplimiento del periodo mínimo de cotización». Por tanto, tales períodos no sólo afectan a la base reguladora y al porcentaje aplicable, sino que también pueden desplegar efectos en la determinación del coeficiente reductor.

Varias precisiones más resultan imprescindibles. En primer término, la modificación operada en los coeficientes reductores en comparación con la Ley 27/2011 supone, de algún modo, un retorno a la situación anterior, porque 1,875 por 100 trimestral equivale a 7,5 por 100 anual, 1,750 por 100 a 7 por $100,1,625$ por 100 a 6,5 por 100 y 1,5 por 100 a 6 por 100. Por consiguiente, sólo se ha procedido a un cambio de temporalidad, lo que, además, implica una ventaja para el interesado, por cuanto al tomarse la parte (fracción) por el todo (antes año, ahora trimestre) la afectación al importe de la pensión será menor cuanto más disminuya el parámetro temporal de referencia.

En segundo lugar, resulta evidente que el período de cotización exigido a efectos de determinar el coeficiente reductor es más amplio que el precedente, pero debe tenerse en cuenta que se computa como cotizado, a estos efectos, el tiempo que reste hasta la edad ordinaria de jubilación. Con todo,

${ }^{23}$ R. Y. Quintanilla Navarro, «Actualización del sistema de Seguridad Social (III): la reforma de la jubilación», Aranzadi Social, vol. 4, núm 8 (2011), pp. 11 y ss. 
este nuevo método resulta más perjudicial que el anterior, por cuanto se han elevado los tiempos de cotización utilizados como referente y el aumento ficticio de cotización no es suficiente compensación. A modo de ejemplo, un trabajador con sesenta y un años de edad exactos y cuarenta de cotización vería disminuida su pensión en un 24 por 100 conforme a la regulación anterior, mientras que tras la reforma se le computarían cuarenta y cuatro años de cotización (cuarenta más los cuatro que le restan hasta la edad ordinaria) y el coeficiente reductor asciende a 26 por 100 . Si se tratase de un trabajador con sesenta y cuatro años y cuarenta de cotización, el coeficiente reductor conforme a la normativa precedente ascendería a un 6 por 100, mientras que con la nueva sería de un 7 por 100 (cuarenta más uno que le resta, insuficiente para alcanzar los cuarenta y un años y medio que permitirían aplicar un menor coeficiente reductor). En cualquier caso, la DA 24. ${ }^{a}$ de la Ley 27/2011 encomienda al gobierno la elaboración de un estudio actuarial al objeto de evaluar la adaptación de estos coeficientes reductores a «los principios de proporcionalidad y contributividad al sistema».

La Ley 27/2011 introdujo una última novedad en relación con la cuantía de la pensión de jubilación anticipada, si bien no está ubicada en el art. 161 bis, sino en los apartados 3 y 4 del art. 163 LGSS. El objetivo de esta novedad consiste en garantizar que la penalización siempre repercuta en el importe de la pensión y evitar, por tanto, que se convierta en irrelevante para supuestos de pensiones muy elevadas. Más concretamente, el hecho de que el tope máximo de cotización esté fijado en cuantías muy superiores a la pensión máxima puede provocar que personas con largas carreras de seguro disfruten de una base reguladora más alta que la pensión máxima, a la que se aplicaría un porcentaje ordinario del 100 por 100 al contar con cotización suficiente, de modo que sería posible que tras la aplicación de la penalización por jubilación anticipada el resultado fuera aún superior al importe de la pensión máxima. En ese escenario la penalización se convierte en irrelevante.

El legislador ha considerado conveniente introducir un factor de corrección en estos casos, ya que no parece adecuado - y desde luego contrario a la solidaridad y a la esencia de un mecanismo de redistribución de la riqueza- que un beneficio de esta índole sea disfrutado exclusivamente por las pensiones de más elevada cuantía. Ese factor de corrección podría haber adoptado configuraciones muy distintas, pero el legislador ha prescindido de la que en principio resultaría más sencilla, y quizá incluso más adecuada, y que supone aplicar el coeficiente reductor directamente sobre la pensión máxima. 
La nueva regla legal opta por una solución diferente que obliga, en primer lugar, a calcular la cuantía de la pensión aplicado el coeficiente reductor y, a continuación, a comparar ese importe con el de la pensión máxima, pero no con la pensión máxima fijada en la Ley de Presupuestos de cada año, sino con un importe ad hoc específico para estas situaciones y que se halla aplicando un coeficiente a esa pensión máxima. Ese coeficiente no coincide con el previsto para la jubilación anticipada, sino que viene prefijado en la norma. La versión inicial de la Ley 27/2011 fijó ese coeficiente en el 0,25 por cada trimestre o fracción de trimestre de anticipación, pero tras el Real Decreto-ley 5/2013 fue elevado al 0,5; cualquiera de ambos resulta notablemente inferior a los previstos en el art. 161 bis. Por cierto, este coeficiente no resulta de aplicación a la jubilación anticipada histórica, así como tampoco a la jubilación con coeficientes reductores de edad por las especialidades del trabajo, ya que en este caso se trata de una modalidad de jubilación ordinaria, por más que el legislador la haya ubicado incorrectamente entre las modalidades de jubilación anticipada.

\section{JUBILACIÓN ANTICIPADA «POR VOLUNTAD DEL INTERESADO»}

Esta modalidad constituye una novedad tras la reforma de 2011-2013 y su denominación y objetivos resultan equívocos, ya que la jubilación es siempre voluntaria y el cese en el trabajo previo a la solicitud de jubilación puede ser voluntario o involuntario. Esta fórmula de jubilación anticipada se convierte, a la postre, en un sustitutivo de la jubilación ordinaria - $-\mathrm{y}$ no exclusivamente en un remedio frente a la exclusión del mercado de trabajo- con requisitos más exigentes y penalización en la cuantía.

\section{Requisitos}

Al margen de la necesidad de acreditar el alta, real o asimilada, ya que no cabe el acceso a la jubilación anticipada desde situaciones de no alta ${ }^{24}$, el art. 161 bis.2.b) LGSS establece tres requisitos específicos para el acceso a esta pensión: edad, período de carencia y cuantía mínima. En cuanto a la edad, el solicitante ha de «tener cumplida una edad que sea inferior

${ }^{24}$ Véase STS de 27 de junio de 1994 (rcud. 3671/1993). 
en dos años, como máximo, a la edad» ordinaria de jubilación, frente a los cuatro años de anticipación que se admiten en la modalidad derivada de cese involuntario por reestructuración empresarial. Por supuesto, no juegan ningún papel los coeficientes reductores de edad que pudieran resultar de aplicación al interesado, ya que tales coeficientes sólo resultan operativos en la jubilación ordinaria. En cualquier caso, por esta vía es posible acceder a la jubilación anticipada a los sesenta y tres años, siempre que se reúna el período de cotización cualificado que permitiría la jubilación ordinaria a los sesenta y cinco.

El segundo requisito, el período de carencia genérico, es más exigente que en la modalidad de cese involuntario, pues se eleva a treinta y cinco años, sin que tampoco se contemplen períodos transitorios. Esta agravación proviene del Real Decreto-ley 5/2013, pues en la redacción original de la Ley 27/2011, y que nunca entró en vigor, ese tiempo de cotización se situaba igualmente en treinta y tres años. Resulta novedosa, sin duda, la tercera de las exigencias, ya que el precepto dispone, como condición sine qua non de acceso a la pensión, una protección para el sistema de Seguridad Social que evite cargas adicionales por la necesidad de abonar complementos por mínimos. De ese modo, «una vez acreditados los requisitos generales y específicos de dicha modalidad de jubilación, el importe de la pensión a percibir ha de resultar superior a la cuantía de la pensión mínima que correspondería al interesado por su situación familiar al cumplimiento de los sesenta y cinco años de edad». Si el propósito consiste en evitar el abono de complementos por mínimos, la denegación de la pensión es una solución drástica; habría resultado más proporcionado permitir causar la pensión excluyendo expresamente los complementos por mínimos.

Como se advirtió, no se alude entre los requisitos a la causa de cese en el trabajo, que resulta indiferente. La denominación legal de esta nueva modalidad — «por voluntad del interesado»- no ha de identificarse con cese voluntario, sino que podrían acceder a esta fórmula cualesquiera personas que cumplieran los requisitos expuestos, con independencia de la causa de extinción del contrato. Es más, en hipótesis está modalidad es accesible en supuestos de cese involuntario por reestructuración empresarial respecto de sujetos que no cumplieran los requisitos específicos para esa otra modalidad de jubilación involuntaria (seis meses de inscripción como desempleado o, en función de la causa de extinción, acreditación del cobro de la indemnización o del inicio del pertinente procedimiento jurisdiccional). 


\section{Cuantía}

Deben entenderse reproducidas en este punto todas las consideraciones efectuadas en relación con la jubilación anticipada por cese involuntario. La única diferencia estriba en un ligero incremento del coeficiente reductor. En concreto, esos coeficientes son los siguientes: la penalización se sitúa en el 2 por 100 por trimestre o fracción que reste para el cumplimiento de la edad ordinaria cuando el beneficiario acredite menos de treinta y ocho años y medio de cotización; en el 1,875 por 100 por trimestre o fracción cuando la cotización se sitúe entre treinta y ocho años y medio y cuarenta y un años y medio; en el 1,750 para carreras de seguro entre cuarenta y un años y medio y cuarenta y cuatro años y medio, y en el 1,625 por 100 por trimestre cuando se acredite un período de cotización igual o superior a cuarenta y cuatro años y seis meses. En términos anuales, esos porcentajes coinciden con el 8, el 7,5, el 7 y el 6,5 por 100 respectivamente, lo que supone incrementar la penalización en medio punto anual en comparación con la jubilación anticipada derivada de una extinción contractual por reestructuración de la empresa.

\section{JUBILACIÓN PARCIAL}

Desde la Ley 40/2007 el legislador ha endurecido las condiciones de acceso a la jubilación parcial, procediendo a una progresiva equiparación con la jubilación anticipada. El Real Decreto-ley 5/2013 insiste en esa misma línea e introduce alguna novedad que sin duda hará menos atractivo para las empresas el recurso a la jubilación parcial.

\section{Objetivos de la reforma}

La jubilación parcial nació a mediados de la década de los ochenta del pasado siglo como una medida más de fomento del empleo y, en concreto, con la intención de facilitar el acceso de los jóvenes a una ocupación. El contexto socioeconómico es suficientemente conocido, pues los procesos de reconversión industrial y el aumento del desempleo aconsejaron potenciar las medidas de sustitución de trabajadores maduros por trabajadores más jóvenes, cuyas perspectivas de encontrar un empleo resultaban, 
en aquel momento, muy reducidas. En esa coyuntura, los poderes públicos apoyaban —y financiaban — las prejubilaciones como una forma de limitar la conflictividad inherente a esos procesos de reconversión industrial. Además, surgen entonces medidas dirigidas a facilitar la sustitución voluntaria de trabajadores mayores por otros más jóvenes enmarcadas en la política de empleo. La jubilación especial a los sesenta y cuatro años, que tiene su origen en el ya derogado Real Decreto-ley 14/1981, de 20 de agosto, y la jubilación parcial constituían ejemplos evidentes.

Sin embargo, la jubilación parcial fue una modalidad escasamente utilizada durante dos décadas, pese a la insistencia del legislador. El aumento de su utilización —se multiplicó por seis entre 2002 y 2008 — ${ }^{25}$ se debió, en buena medida, a una interpretación, hasta cierto punto forzada, de la posibilidad que ofrece el art. $34 \mathrm{ET}$ de pactar una «distribución irregular de la jornada a lo largo del año». La concentración de la jornada remanente del jubilado parcial y, en su caso, la acumulación del tiempo de trabajo del relevista es una propuesta mucho más atractiva desde la perspectiva empresarial y también desde la del trabajador, pues, en último término, permite al jubilado parcial acceder de facto a un retiro prácticamente completo mucho antes del cumplimiento de la edad ordinaria sin sufrir penalización alguna por tal anticipación.

La jubilación parcial se convirtió en una fórmula ordinaria - por lo frecuente de su utilización - para abandonar la vida activa, y ello se debe a la modificación de sus objetivos, o más bien a la instrumentalización de la institución con fines ajenos a las pretensiones del legislador. Como puso de manifiesto el CES, «el objetivo de esta figura en el momento de su creación era facilitar la permanencia en el empleo de los trabajado-

${ }^{25}$ En 2002 el número de jubilaciones parciales se situó en 6.806 (un 3,6 por 100 del total de nuevos beneficiarios de la pensión de jubilación, que ascendió a 187.753). Desde ese momento ha crecido a un ritmo medio de 5.000 jubilaciones parciales por año: 10.327 en 2003 (un 5,4 por 100 de las 190.574 nuevas altas en la pensión de jubilación), 15.780 en 2004 (un 8,4 por 100 de los 187.104 nuevos pensionistas de jubilación), 21.232 en 2005 (un 8 por 100 de las 265.270 nuevas altas en la pensión de jubilación), 27.354 en 2006 (11,6 por 100 de los 235.129 nuevos pensionistas de jubilación), 29.445 en 2007 (12,7 por 100 de las 231.784 nuevas pensiones de jubilación) y 36.884 en 2008. En el primer semestre de 2009 se produjeron otras 16.459 jubilaciones parciales. Los porcentajes sobre el total de jubilaciones son considerablemente más altos si se excluyen las pensiones de jubilación solicitadas por trabajadores autónomos (más de 40.000 al año) o si se toma exclusivamente como referencia el Régimen General, donde las nuevas altas por jubilación no superan de ordinario las 150.000 cada año. Véase http://www.sepe.es/contenidos/cifras/datos_estadisticos/ contratos/datos/estadisticas_nuevas.html, http://www.mtas.es/estadisticas/ANUARIO.htm

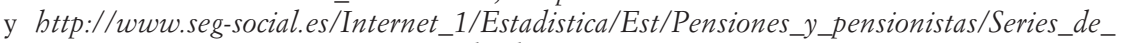
Pensiones_en_vigor_y_Pensionistas/index.htm. 
res mayores, al tiempo que una transición gradual y flexible a la jubilación». Sin embargo, se constata que «la realidad se ha podido desviar por otros cauces, como pueden indicar varios datos [...]: más del 98 por 100 de los jubilados parciales acceden con sesenta años; prácticamente todos se acogen a la reducción de jornada máxima permitida (el 85 por 100); el 83,6 por 200 tienen treinta y cinco o más años cotizados y cuentan con una base reguladora alta en media (1.613 euros), lo que redunda en que la cuantía de su jubilación parcial sea superior a la media de los jubilados mayores de sesenta y cinco años» ${ }^{26}$.

En este contexto, los poderes públicos se vieron obligados a contemplar la jubilación parcial no sólo como una medida de fomento del empleo, sino también como una medida de Seguridad Social — vinculando la política de empleo al sostenimiento del sistema ${ }^{27}$-, porque la jubilación parcial, tal y como se ha articulado en la práctica, no alivia las cargas financieras del sistema de Seguridad Social —más bien al contrario- y tampoco consigue, salvo excepciones, que el trabajador continúe prestando servicios más allá de la edad ordinaria. En verdad, la jubilación parcial se convirtió en un instrumento, aparentemente eficaz, de la política de empleo, pues facilita procesos de reorganización empresarial y contribuye al rejuvenecimiento de plantillas. No en vano, el II Acuerdo para el Empleo y la Negociación Colectiva 2012, 2013 y 2014 (BOE, de 6 de febrero de 2012) insiste en que «la jubilación parcial y el contrato de relevo deben seguir siendo un instrumento adecuado para el mantenimiento del empleo y el rejuvenecimiento de plantillas».

La Ley 40/2007 trató de minimizar el impacto sobre el erario público de esta modalidad aumentando la edad hasta sesenta y un años, incrementando el período mínimo de carencia necesario hasta treinta años e introduciendo nuevos requisitos como una antigüedad mínima de seis años y la correspondencia de al menos el 65 por 100 entre las bases de cotización del jubilado parcial y el relevista cuando el relevista no fuera asignado al mismo puesto o a uno similar. Pese a que inicialmente se contempló una aplicación paulatina, el Real Decreto-ley 8/2010 suprimió los períodos transitorios con efectos de 25 de mayo de 2010, aunque admitió la jubilación anterior a los sesenta y un años de trabajadores afectados por compromisos de jubilación parcial adoptados en expedientes de regulación de empleo o por medio de

\footnotetext{
${ }^{26}$ Cfr. Cauces. Cuadernos del Consejo Económico y Social, núm. 2 (2007), p. 22.

27 Véase J. López GANDía, La nueva regulación de la jubilación parcial tras la reforma del 2007, Albacete, Bomarzo, 2008, p. 5.
} 
convenios y acuerdos colectivos de empresa - y no de ámbito superior- ${ }^{28}$ previos a esa norma. Por esa vía se permitió, hasta 31 de diciembre de 2012, la jubilación parcial a los sesenta años cuando el trabajador relevista era contratado a jornada completa y por tiempo indefinido, y a los sesenta años y seis meses si era contratado en otras condiciones.

La Ley 27/2011 y el Real Decreto-ley 5/2013 han propiciado un nuevo endurecimiento de los requisitos de acceso a la jubilación parcial, continuando con la misma filosofía que había inspirado la Ley 40/2007 en este punto. En la configuración vigente tras esa reforma será mucho más complejo que la jubilación parcial pueda continuar sirviendo a esos fines de política de empleo y reestructuración empresarial, y con ello la utilización de esta fórmula se reducirá notablemente ${ }^{29}$. No obstante, gracias a las disposiciones transitorias se prevé una congelación del régimen jurídico precedente hasta 2019 en determinados casos.

\section{Requisitos de acceso}

Al margen de la novedosa ampliación del campo de aplicación de la jubilación parcial a los socios trabajadores o de trabajo de las cooperativas asimilados a trabajadores por cuenta ajena, y que conlleva la contratación como relevista de un desempleado que se incorporará en calidad de socio trabajador o de socio de trabajo (DA 64. ${ }^{a}$ LGSS), la reforma destaca por haber extremado el rigor en el acceso a esta modalidad. Cierto es que la Ley 27/2011, en su redacción original, se mostraba más comedida, pues se había limitado a extender la obligación de correspondencia de al menos el 65 por 100 entre las bases de cotización del jubilado parcial y el relevista, obligación que ya no quedaría circunscrita a supuestos de asignación de funciones no similares, sino que se generalizaría. Además, se contemplaba, también como novedad, que a efectos de cotización el jubilado parcial debería ser considerado como trabajador a tiempo completo, de modo que la reducción de jornada afectaría sin duda al tiempo de trabajo y al salario, pero no al importe de la cuota a ingresar. Se trata, de algún modo, de una cotización de «solidaridad» por el acceso prematuro a la jubilación. El Real Decreto-ley 29/2012 suspendió la entrada en vigor

28 Véase STS de 25 de febrero de 2013 (rcud. 560/2012).

29 J. LÓPEZ GANDíA, «La jubilación parcial tras la reforma de las pensiones», Documentación Laboral, núm. 99 (2013), p. 80, y A. Selma Penalva, «¿Los últimos pasos del contrato de relevo?», REDT, núm. 164 (2014), pp. 87 y ss. 
de esa reforma hasta la aprobación de otro marco normativo contenido en el Real Decreto-ley 5/2013. El nuevo régimen jurídico se caracteriza por introducir notables restricciones en el acceso a la jubilación parcial, alterando sustancialmente las exigencias de edad, período de carencia y reducción de jornada.

En relación con la edad se contemplan tres edades mínimas, ya que, con buen criterio, los mutualistas que puedan disfrutar de la jubilación anticipada histórica cuentan con la posibilidad de causar la jubilación parcial a los sesenta años. En cuanto al resto, se configura una edad distinta en función del período de carencia, en una configuración similar a la jubilación ordinaria. El período mínimo de carencia en materia de jubilación parcial se eleva hasta treinta y tres años, en consonancia con la jubilación anticipada. Los trabajadores que alcancen ese período de cotización podrán jubilarse parcialmente a los sesenta y cinco años. Cabe también la posibilidad de jubilación parcial a los sesenta y tres años, siempre que el interesado reúna un período de cotización cualificado fijado en treinta y seis años y seis meses de cotización. No se trata de requisitos exactamente coincidentes con los de la jubilación anticipada, pero sin lugar a dudas la sintonía es evidente.

Este endurecimiento de las condiciones viene acompañado de un período transitorio con el horizonte de 2027, buscando dulcificar las consecuencias del endurecimiento de los requisitos y tratando, asimismo, de acompasar la elevación de la edad de jubilación parcial y de la edad de jubilación ordinaria. Ese período transitorio se configura de la siguiente forma:

\begin{tabular}{|l|l|l|l|}
\hline $\begin{array}{c}\text { Año del } \\
\text { becho } \\
\text { causante }\end{array}$ & \multicolumn{2}{|c|}{$\begin{array}{c}\text { Edad exigida según periodos cotizados } \\
\text { en el momento del hecho causante }\end{array}$} & $\begin{array}{c}\text { Edad exigida con 33 años cotizados } \\
\text { en el momento del hecho causante }\end{array}$ \\
\hline 2013 & 61 y 1 mes & 33 años y 3 meses o más & 61 y 2 meses \\
\hline 2014 & 61 y 2 meses & 33 años y 6 meses o más & 61 y 4 meses \\
\hline 2015 & 61 y 3 meses & 33 años y 9 meses o más & 61 y 6 meses \\
\hline 2016 & 61 y 4 meses & 34 años o más & 61 y 8 meses \\
\hline 2017 & 61 y 5 meses & 34 años y 3 meses o más & 61 y 10 meses \\
\hline 2018 & 61 y 6 meses & 34 años y 6 meses o más & 62 años \\
\hline 2019 & 61 y 8 meses & 34 años y 9 meses o más & 62 y 4 meses \\
\hline 2020 & 61 y 10 meses & 35 años o más & 62 y 8 meses \\
\hline 2021 & 62 años & 35 años y 3 meses o más & 63 años \\
\hline 2022 & 62 y 2 meses & 35 años y 6 meses o más & 63 y 4 meses \\
\hline 2023 & 62 y 4 meses & 35 años y 9 meses o más & 63 y 8 meses \\
\hline
\end{tabular}




\begin{tabular}{|l|l|l|l|}
\hline $\begin{array}{c}\text { Año del } \\
\text { becho } \\
\text { causante }\end{array}$ & \multicolumn{2}{|c|}{$\begin{array}{c}\text { Edad exigida según periodos cotizados } \\
\text { en el momento del hecho causante }\end{array}$} & $\begin{array}{c}\text { Edad exigida con 33 años cotizados } \\
\text { en el momento del hecho causante }\end{array}$ \\
\hline 2024 & 62 y 6 meses & 36 años o más & 64 años \\
\hline 2025 & 62 y 8 meses & 36 años y 3 meses o más & 64 y 4 meses \\
\hline 2026 & 62 y 10 meses & 36 años y 3 meses o más & 64 y 8 meses \\
\hline 2027 y ss. & 63 años & 36 años y 6 meses & 65 años \\
\hline
\end{tabular}

La segunda modificación relevante afecta al período de carencia, que, como se dijo, se eleva de treinta a treinta y tres años, sin períodos transitorios, en consonancia con la jubilación anticipada. Ese período de cotización de treinta y tres años permite el acceso a la jubilación parcial a partir de los sesenta y cinco años o de la edad que corresponda hasta 2027 conforme a la tabla ya transcrita, en el paulatino aumento de la edad mínima de sesenta y uno a sesenta y cinco años. En caso de que el interesado acredite un período de carencia superior a treinta y tres años podría beneficiarse de una rebaja de la edad mínima.

Conviene precisar que la Ley 27/2011 introdujo una modificación en el apartado d) del art. 166.2 LGSS en el sentido de disminuir el período de carencia genérica a veinticinco años en lugar de treinta «en el supuesto de personas con discapacidad o trastorno mental». Esa modificación, que entró en vigor el 1 de enero de 2013, no se vio afectada por la suspensión aplicativa durante tres meses de determinados preceptos de la Ley 27/2011 decidida por el Real Decreto-ley 29/2012. El Real Decretoley 5/2013 alteró levemente la regla al eliminar la referencia al trastorno mental y concretar que el grado de discapacidad ha de ser igual o superior al 33 por 100 .

Es probable, no obstante, que la exigencia que más incida en la utilización futura de esta figura sea la vinculada a los límites de reducción de jornada, porque el jubilado parcial ya no podrá ser considerado un trabajador marginal. Desde el Real Decreto-ley 5/2013 la reducción de su jornada debe oscilar entre un mínimo de un 25 por 100 y un máximo de un 50 por 100 en relación con la de un trabajador a tiempo completo comparable (límite, por cierto, que resulta de aplicación a la jubilación parcial posterior a la edad ordinaria, lo que es incoherente con el propósito de fomentar el retraso en la jubilación, ya que en dicha modalidad los requisitos deberían configurarse de manera mucho más generosa). Se admite, no obstante, una reducción de jornada más amplia, de hasta el 75 por 100, a condición de que «el relevista sea contratado a jornada completa median- 
te un contrato de duración indefinida». En este caso, el contrato de relevo debe mantenerse «al menos durante una duración igual al resultado de sumar dos años al tiempo que le falte al trabajador sustituido para alcanzar la edad de jubilación» ordinaria, con independencia de cuándo se extinga el contrato del jubilado parcial. Si el contrato de relevo se extinguiera antes el empleador debe contratar otro relevista en un plazo de quince días, pues de lo contrario será «responsable del reintegro de la pensión que haya percibido el pensionista a tiempo parcial» [art. 166.2.f) LGSS, tras el Real Decreto-ley 5/2013]. Todo ello, claro está, sin perjuicio de la aplicación de reglas transitorias ${ }^{30}$.

Este nuevo marco de reducción de jornada desincentivará el recurso a la jubilación parcial cuando la empresa no esté dispuesta a contratar a un relevista en esas condiciones, y ése es un efecto sin duda buscado y deseado. El legislador no ha prohibido ni restringido la concentración de jornada, pero estos nuevos umbrales de reducción del tiempo de trabajo restan un notable atractivo a esa figura, máxime cuando esos límites han entrado en vigor de manera inmediata, al no venir prevista ninguna regla de aplicación gradual.

También es relevante la modificación operada en el requisito de correspondencia de las bases de cotización. La Ley 27/2011 modificó el apartado e) del art. 166 LGSS, en el sentido de eliminar esa alternativa entre la asignación de funciones similares y la correspondencia entre las bases de cotización, decantándose por esta última opción. Esa correspondencia, también cifrada en el 65 por 100, ya no se refiere a «la base por la que venía cotizando el trabajador que accede a la jubilación parcial», sino al «promedio de las bases de cotización correspondientes a los seis últimos meses del período de base reguladora de la pensión de jubilación parcial», regla similar, pero que concreta el parámetro de comparación. En todo caso, si el relevista presta servicios a tiempo parcial parece necesario, a efectos de homogeneizar los términos de comparación, que se tome como referencia la base de cotización —y, por tanto, el salario- que correspondería al relevista si prestara servicios a jornada completa.

La reforma de la jubilación parcial requería una correlativa adecuación del art. 12 ET en sus apartados 6 y 7. Concretamente, el art. 12.7.d) ET comienza de la misma forma — «el puesto de trabajo del trabajador

30 I. A. Rodríguez CaRdo, La jubilación parcial tras la reforma de 2013, Valladolid, Lex Nova, 2013, pp. 127 y ss., y J. A. MARTínez LuCAS, «El nuevo régimen jurídico de la jubilación parcial», Actualidad Laboral, núm. 5 (2013), p. 637. 
relevista podrá ser el mismo del trabajador sustituido»-, pero omite, significativamente, la referencia a «uno similar» o a la ubicación en la misma categoría o grupo, y desaparece la excepcionalidad en la asignación de funciones distintas por la necesidad de probar «requerimientos específicos». El precepto sigue expresándose en términos potestativos — «podrá»—, de modo que la reforma implica una absoluta flexibilización en la asignación de funciones. El empleador cuenta con completa libertad para decidir el puesto al que se asignará al trabajador relevista, ya que ni siquiera es obligado que preste servicios en el mismo centro de trabajo e incluso resultaría admisible un traslado al extranjero ${ }^{31}$. La limitación no se encuentra directamente en las funciones, sino en la retribución, pues debe respetarse la garantía mínima de correspondencia de las bases de cotización cualquiera que sean las funciones encomendadas al relevista. De este modo, la correspondencia entre las bases de cotización sustituye al criterio de la equivalencia de funciones.

Resulta evidente que esa apuesta por la comparación de bases de cotización — de salarios en definitiva - olvida que el jubilado parcial, por su experiencia y antigüedad en la empresa, disfruta de complementos de carácter personal inaccesibles para el relevista. En consecuencia, parece más razonable comparar el salario vinculado a cada puesto de trabajo en atención al convenio colectivo, con independencia del trabajador que lo ocupe, que no el montante total de la retribución que corresponde a cada uno. No obstante, el hecho de que se exija una equivalencia del 65 por 100 entre ambas bases de cotización ofrece un margen muy razonable que debería ser suficiente para que los complementos personales no jueguen un papel decisivo.

En caso de no respetarse la garantía mínima habría que proceder o bien a asignar otro puesto al relevista, o bien a incrementar su salario por encima de lo establecido en el convenio, opción esta última más beneficiosa para el trabajador, pero perjudicial para la empresa, no sólo por el coste económico que supone, sino también por el malestar que puede generar en los trabajadores que desempeñan las mismas tareas que el relevista y que percibirían por ello una retribución inferior a la de un trabajador de nueva incorporación. Por cierto, esta opción no resulta operativa en la mayoría de ocasiones si el jubilado parcial está comprendido en un régimen del sistema de Seguridad Social que calcule la base de cotización en función del

31 Ampliación de 18 de julio de 2013 de la Subdirección General de Ordenación y Asistencia Jurídica del INSS del criterio 11/2003-04 (RJ 111/2013) (BISS, julio de 2013). 
salario ( $v$. gr., Régimen General) y el relevista en un régimen en el que las bases de cotización se encuentren predeterminadas ( $v$. gr., RETM respecto de los grupos 2 y 3 y REMC). En la medida en que aumentar el salario del relevista no incrementaría su base de cotización, el cumplimiento de la exigencia legal parece obligar a una modificación del puesto del relevista, de manera tal que también se altere el régimen de encuadramiento en el sistema de Seguridad Social, aunque en este punto cabe abogar por una interpretación flexible que exonere de responsabilidad al empresario por una circunstancia ajena a su control.

La norma establece la obligación, pero no la sanción o la consecuencia del incumplimiento. La entidad gestora está facultada para denegar la solicitud de pensión de jubilación parcial si la empresa no acredita inicialmente la correspondencia entre las bases de cotización, pero no se concreta qué sucede si el incumplimiento se produce sobrevenidamente. En la medida en que no tiene lugar un cese, no cabe aplicar la DA 2. ${ }^{a}$ del RD 1132/2002. En verdad, se produce en este caso un supuesto de infracotización sui generis que debe dar lugar a las responsabilidades administrativas y de Seguridad Social pertinentes. La intervención del Derecho penal en tales supuestos parece excesiva en atención al principio de intervención mínima.

En cuanto al último de los requisitos, el nuevo art. 166.2.g) LGSS, introducido por la Ley 27/2011 y el Real Decreto-ley 5/2013, dispone que «durante el período de disfrute de la jubilación parcial, empresa y trabajador cotizarán por la base de cotización que, en su caso, hubiese correspondido de seguir trabajando éste a jornada completa». La redacción es clara e impide adecuar la base de cotización a la nueva condición de trabajador a tiempo parcial del jubilado parcial con un propósito eminentemente recaudatorio. No obstante, el legislador no implanta esa exigencia con carácter inmediato, sino de forma muy gradual, porque la base de cotización durante 2013 equivale al 50 por 100 (30 por 100 en la redacción inicial de la Ley 27/2011, aumentado a 50 por 100 tras el Real Decreto-ley $5 / 2013$, en consonancia con el nuevo límite de reducción de jornada, aunque sin contemplar eventuales reducciones de jornada hasta el 75 por 100) de la base de cotización que hubiera correspondido a jornada completa, siempre, claro está, que el trabajador desempeñe una jornada inferior. Por cada año transcurrido a partir del año 2014 se incrementará un 5 por 100 más hasta alcanzar el 100 por 100 de la base de cotización que le hubiera correspondido a jornada completa. El requisito, por tanto, será de plena aplicación en 2023 y no en 2027 , como se derivaba de la redacción inicial de la Ley 27/2011. 
Es claro que se trata de porcentajes mínimos, de modo que durante el período transitorio se utilizará la base de cotización real cuando el tiempo de trabajo se encuentre por encima de la escala que deriva de esa disposición transitoria. Dicho en otros términos, un jubilado parcial que acuerde prestar servicios con una jornada del 60 por 100 cotizará por la base que derive del salario que perciba realmente hasta 2016, año en el que su base de cotización no puede resultar inferior al 65 por 100 de la que correspondería a un trabajador a tiempo completo. Hasta ese momento, el incremento del 5 por 100 afecta a la base mínima teórica o ficticia, pero no a la base de cotización real, que respetaría ese umbral.

\section{COMPATIBILIDAD ENTRE LA PENSIÓN DE JUBILACIÓN Y EL TRABAJO}

El art. 165 LGSS disponía, antes de la Ley 27/2011 y del Real Decretoley $5 / 2013$, que «el disfrute de la pensión de jubilación, en su modalidad contributiva, será incompatible con el trabajo del pensionista» ${ }^{32}$, entendiendo por tal, a tenor del art. 16 de la Orden de 18 de enero de 1967, «todo trabajo del pensionista, por cuenta ajena o propia, que dé lugar a su inclusión en el campo de aplicación del Régimen General o de alguno de los Regímenes Especiales de la Seguridad Social».

Las excepciones que tradicionalmente se han contemplado a esa regla general se vinculan, de ordinario, a actividades con cierto carácter residual, de naturaleza más honorífica o de reconocimiento de méritos que propiamente productiva o profesional, como sucede con los profesores de universidad eméritos (DA 12. ${ }^{a}$ LGSS) ${ }^{33}$ y el personal licenciado sanitario emérito (DA 43. ${ }^{a}$ LGSS) ${ }^{34}$. En consecuencia, el desempeño de un trabajo productivo resultaba incompatible con la pensión — sin perjuicio de

32 M. A. Castro Argüelles, «Art. 165», en A. Martín Valverde y J. García Murcia (dirs.), Ley General de Seguridad Social. Comentada y con jurisprudencia, Madrid, La Ley, 2009, pp. 1205 y ss., y J. CABEZA PEREIRO, «La incompatibilidad del trabajo con la pensión de jubilación total», en J. L. Monereo Pérez, C. Molina Navarrete y M. N. Moreno Vida (coords.), La Seguridad Social a la luz de sus reformas pasadas, presentes y futuras, Granada, Comares, 2008, pp. 639 y ss.

33 F. Salvador Pérez, «Disposición Adicional 12.. ${ }^{2} »$, en A. Martín Valverde y J. GarCía Murcia (dirs.), Ley General de Seguridad Social. Comentada y con jurisprudencia, Madrid, La Ley, 2009, pp. 1724 y ss.

${ }^{34}$ I. A. Rodríguez Cardo, «Disposición Adicional 43.. ${ }^{a} »$, en A. Martín Valverde y J. García Murcia (dirs.), Ley General de Seguridad Social. Comentada y con jurisprudencia, Madrid, La Ley, 2009, pp. 1825 y ss. 
la especial situación de los profesionales colegiados que opten por una mutualidad alternativa $-{ }^{35}$ hasta que el Real Decreto-ley 16/2001, primero, y la Ley 35/2002, después, admitieron que el derecho a la pensión de jubilación no se suspendería, aunque la cuantía se vería reducida proporcionalmente, cuando el jubilado decidiera reincorporarse a la actividad desempeñando un trabajo asalariado a tiempo parcial. Ésa es la situación que el legislador bautizó como «jubilación flexible» y cuyo régimen jurídico se detalla en el Real Decreto 1132/2002, de 31 de octubre.

La Ley 27/2011 y el Real Decreto-ley 5/2013 han modificado sustancialmente el régimen de compatibilidad entre la pensión de jubilación y el trabajo, aunque no han alterado la jubilación flexible. En primer lugar, la Ley 27/2011 introdujo un apartado 4 en el art. 165 LGSS mediante el cual declaraba la plena compatibilidad entre la pensión y un trabajo por cuenta propia «cuyos ingresos anuales totales no superen el salario mínimo interprofesional en cómputo anual». El precepto aclara que «quienes realicen estas actividades económicas no estarán obligados a cotizar por las prestaciones de la Seguridad Social». El propósito de la norma consiste en facilitar al pensionista vías de ingresos adicionales - y cabe incluso continuar la actividad previa a la jubilación — ${ }^{36}$, si bien habría sido necesaria una adaptación del campo de aplicación del RETA, ya que si la actividad se realiza con habitualidad medida en un parámetro temporal procede el alta y la cotización en el RETA con independencia de los rendimientos obtenidos $^{37}$. Es cierto que en alguna ocasión la jurisprudencia ha admitido la sustitución de ese parámetro temporal por un criterio basado en ingresos, pero la doctrina del TS «ha sido mal entendida y peor aplicada ${ }^{38}$, por cuanto el mismo criterio se ha utilizado para otros colectivos ${ }^{39}$ a pesar de

35 Véase Orden TIN/1362/2011, de 23 de mayo, y DA 37.. a de la Ley 27/2011.

36 Véase STSJ del País Vasco de 8 de julio de 2014 (recurso 1107/2014).

37 Véase M. J. Cervilla Garzón, «Revisión de la "habitualidad" exigida a los trabajadores autónomos a la luz de su estatuto y de las resoluciones jurisprudenciales», Actualidad Laboral, núm. 16 (2011), pp. 1887 y ss.

${ }^{38}$ Cfr. T. Sala Franco y A. Blasco Pellicer, «La nueva regulación del RETA», Actualidad Laboral, núm. 8 (2004), p. 923.

${ }^{39}$ En relación con una modista véase STSJ de Navarra de 18 de febrero de 2004 (recurso 43/2004); sobre el titular de una explotación de engorde y cría de ganado porcino véase STSJ de Castilla y León (Burgos) de 11 de noviembre de 2003 (recurso 1010/2003); acerca de un columnista de prensa véase STSJ de Cataluña de 6 de junio de 2003 (recurso 7180/2002); relativa a una masajista véase STSJ del País Vasco de 3 de junio de 2003 (recurso 872/2003); respecto de una psicóloga véase STSJ de Castilla y León (Burgos) de 17 de septiembre de 2002 (recurso 750/2002), y sobre un asesor contable véase STSJ del País Vasco de 11 de junio de 2002 (recurso 836/2002). 
que nació como remedio excepcional «aplicable en exclusiva a los subagentes de seguros» ${ }^{40}$. Nótese, en todo caso, que el nuevo art. 165.4 LGSS únicamente alude a la obligación de cotizar, pero no exime de las exigencias relativas a los actos de encuadramiento, y en particular del alta ${ }^{41}$. La interpretación administrativa consideró inicialmente que el art. 165.4 LGSS no suponía novedad alguna, decantándose por declarar la incompatibilidad en todos los supuestos en los que proceda el alta en el RETA y la compatibilidad en caso contrario ${ }^{42}$. Esa posición fue posteriormente matizada, por cuanto los ingresos obtenidos no son el único criterio para medir la habitualidad, ni tampoco absolutamente determinantes para el acceso al RETA, amén de que se suscitaba un problema práctico para determinar la incompatibilidad en el momento de inicio de la actividad, ya que se desconoce el rendimiento económico que se generará ${ }^{43}$.

El Real Decreto-ley 5/2013 mantuvo vigentes ambas posibilidades y además añadió un nuevo supuesto que supone un trascendente cambio de filosofía con el triple objetivo, según su exposición de motivos, de «favorecer el alargamiento de la vida activa, reforzar la sostenibilidad del sistema de Seguridad Social y aprovechar en mayor medida los conocimientos y experiencia de estos trabajadores». El art. 2 de esa norma establece una excepción a las reglas de incompatibilidad establecidas por el art. 165 LGSS al declarar compatible la pensión de jubilación «con la realización de cualquier trabajo por cuenta ajena o por cuenta propia del pensionista»; actividad, por supuesto, que debe estar regida por la legislación española ${ }^{44}$. Esa inicial declaración se suaviza a continuación al detallar las condiciones específicas para tal compatibilidad. En primer lugar, no toda pensión de jubilación es susceptible de encajar en este régimen privilegiado, sino sólo la jubilación ordinaria, ya que es menester acceder a una edad igual o superior a la que en cada momento se establezca como edad legal, sin posibilidad de aplicar coeficientes reductores. Además, el interesado deberá disfrutar de un porcentaje aplicable a la base reguladora de un 100 por 100, lo que le obligará a contar con una amplia carrera de

\footnotetext{
${ }^{40}$ Cfr. STS de 9 de diciembre de 2003 (rcud. 895/2002).

${ }^{41}$ A. Selma Penalva, «Posibilidades de compatibilizar pensión de jubilación con el trabajo», Aranzadi Social, vol. 6, núm. 2 (2013), pp. 65 y ss.

${ }_{42}$ Véase criterio 27/2001, de 11 de noviembre de 2011 (BISS, julio 2013).

${ }^{43}$ Véase ampliación de 4 de octubre de 2012 de la Subdirección General de Ordenación y Asistencia Jurídica del INSS del criterio de aplicación 27/2001 (BISS, octubre de 2012).

${ }^{4}$ Véase criterio de aplicación 5/2014, de 24 de abril, de la Subdirección General de Ordenación y Asistencia Jurídica del INSS (BISS, abril de 2014).
} 
seguro $^{45}$. En todo caso, nada impide que se continúe realizando el mismo trabajo que se desarrollaba en el momento de causar la pensión, y los efectos de la compatibilidad se producirían tras la presentación de la solicitud - $\mathrm{o}$ en el momento de los tres meses siguientes que indique el propio interesado-, salvo en caso de trabajadores autónomos, ya que la compatibilidad en este supuesto surtirá efectos desde el primer día del mes que se indique en la solicitud ${ }^{46}$.

Evidentemente, el legislador pretende que esta compatibilidad suponga un aumento neto de empleo, de modo que el pensionista de jubilación que compatibiliza su pensión con el trabajo no debe sustituir a un trabajador ordinario. Por ello, la DA 1. ${ }^{a}$ del Real Decreto-ley 5/2013 establece una serie de obligaciones y límites para la empresa dirigidos a garantizar el «mantenimiento del empleo durante la percepción de la pensión de jubilación compatible con el trabajo». Es, desde luego, una precisión que se vincula -implícitamente, cierto es- a la compatibilidad con un trabajo asalariado y que prima facie no alcanza al trabajo por cuenta propia. El legislador, quizás, debería haber establecido una exigencia de calado similar en caso de que la actividad compatible convirtiera al interesado en TRADE, o incluso en socio trabajador de una cooperativa.

Concretamente, no pueden ser receptoras de esta clase de prestaciones de servicios las empresas que hayan «adoptado decisiones extintivas improcedentes en los seis meses anteriores a dicha compatibilidad». Parece indiferente la modalidad de despido utilizada, si bien las extinciones deben afectar a puestos de trabajo del mismo grupo profesional en el que ubicaría el jubilado que retorna al trabajo. No es ésta la única obligación, pues «una vez iniciada la compatibilidad entre pensión y trabajo, la empresa deberá mantener, durante la vigencia del contrato de trabajo del pensionista de jubilación, el nivel de empleo existente en la misma antes de su inicio» tomando «como referencia el promedio diario de trabajadores de alta en la empresa en el periodo de los noventa días anteriores a la compatibilidad, calculado como el cociente que resulte de dividir entre noventa la suma de los trabajadores que estuvieran en alta en la empresa en los noventa días inmediatamente anteriores a su inicio».

El precepto matiza, finalmente, que «no se considerarán incumplidas la obligaciones de mantenimiento del empleo anteriores cuando el con-

${ }^{45}$ M. J. Asquerino Lamparero, «La jubilación anticipada», Aranzadi Social, vol. 6, núm. 3 (2013), pp. 177 y ss.

${ }^{46}$ Véase criterio de aplicación 3/2014, de 4 de marzo, de la Subdirección General de Ordenación y Asistencia Jurídica del INSS (BISS, marzo de 2014). 
trato de trabajo se extinga por causas objetivas o por despido disciplinario cuando uno u otro sea declarado o reconocido como procedente, ni las extinciones causadas por dimisión, muerte, jubilación o incapacidad permanente total, absoluta o gran invalidez de los trabajadores, o por la expiración del tiempo convenido o realización de la obra o servicio objeto del contrato».

Conviene tener presente, en todo caso, que no se aclaran las consecuencias del incumplimiento, pues no se prevé una sanción administrativa específica ni se contempla la obligación de abono de la pensión como sucede con los incumplimientos empresariales relativos a la jubilación parcial. Desde luego, no parece que las consecuencias puedan perjudicar al beneficiario, al que no cabe imputar responsabilidad por decisiones que escapan a su control. La Administración, por cierto, aboga por exigir al empleador el consentimiento como condición de compatibilidad ${ }^{47}$, exigencia no contemplada expresamente en la Ley, pero razonable por motivos de gestión, y también para justificar que el beneficiario no tenga que asumir el riesgo de devolver cantidad alguna.

Si concurren esas condiciones, el interesado podrá mantener su pensión de jubilación, pero no en su cuantía íntegra, sino del «50 por 100 del importe resultante en el reconocimiento inicial, una vez aplicado, si procede, el límite máximo de pensión pública, o del que se esté percibiendo, en el momento de inicio de la compatibilidad con el trabajo, excluido, en todo caso, el complemento por mínimos, cualquiera que sea la jornada laboral o la actividad que realice el pensionista» (art. 3 del Real Decreto-ley $5 / 2013)^{48}$, si bien la Administración ha entendido que en supuestos de pensiones «internacionales» en las que haya debido recurrirse a la totalización es menester matizar esta regla ${ }^{49}$. En materia de cotización se siguen pautas similares a las del art. 112 bis LGSS, ya que únicamente se ingresarán cuotas por incapacidad temporal y por contingencias profesionales. El precepto no aclara si esa cotización por contingencias

${ }^{47}$ Ibid.

${ }^{48}$ M. Rodríguez-Piñero y Bravo-Ferrer, F. Valdés Dal-Ré y M. E. Casas Baamonde, «La nueva regulación de la jubilación en el RDL 5/2013, de 15 de marzo, de medidas para favorecer la continuidad de la vida laboral de los trabajadores y promover el envejecimiento activo», $R L$, núm. 5 (2013), pp. 16-17; J. MuÑOz MolinA, «Acercamiento a las últimas novedades en materia de jubilación», Aranzadi Social, vol. 6, núm. 5 (2013), pp. 131 y ss., e Y. Sánchez-Urán Azaña y J. Gil Plana, Pensión de jubilación. Últimas reformas legales, Madrid, Civitas, 2014, pp. 173 y ss.

${ }^{49}$ Véase criterio de aplicación 5/2014, de 24 de abril, de la Subdirección General de Ordenación y Asistencia Jurídica del INSS (BISS, abril de 2014). 
profesionales resulta obligatoria en supuestos de compatibilidad con un trabajo por cuenta propia en el que la cotización por riesgos profesionales resulta voluntaria. Es probable que la respuesta deba ser negativa a la vista de la escasa precisión y contundencia legal, ya que la formulación es demasiado genérica. Además, se añade una nueva «cotización especial de solidaridad del 8 por 100, no computable para las prestaciones, que en los regímenes de trabajadores por cuenta ajena se distribuirá entre empresario y trabajador, corriendo a cargo del empresario el 6 por 100 y del trabajador el 2 por 100». Esta compatibilidad finaliza cuando se extinga la obligación de cotizar, recuperando el beneficiario la cuantía íntegra de la pensión al día siguiente (o el primer día del mes siguiente en caso de autónomos) $)^{50}$.

El Real Decreto-ley 5/2013 no deroga el RD 1132/2002 y tampoco establece reglas particulares para la jubilación flexible, pese a que pueden observarse puntos de coincidencia que propiciarán fricciones. Desde luego, el Real Decreto-ley 5/2013 admite una compatibilidad mucho más amplia que el RD 1132/2002, ya que abarca tanto el trabajo asalariado como el autónomo, y la jornada completa o parcial. Por su parte, la jubilación flexible entra en juego en cualquier modalidad de jubilación completa, no sólo la ordinaria, a diferencia de la compatibilidad prevista en el Real Decreto-ley 5/2013.

Ahora bien, el hecho de que los respectivos ámbitos de aplicación no resulten exactamente coincidentes no elimina las dificultades, ya que si un beneficiario de la pensión de jubilación ordinaria que disfrute de una pensión del 100 por 100 de su base reguladora, en los términos del Real Decreto-ley $5 / 2013$, inicia un trabajo por cuenta ajena a tiempo parcial dentro de los porcentajes previstos en el art. 12.6 ET, el supuesto encaja tanto en las reglas del Real Decreto-ley 5/2013 como en el RD 1132/2002. El principio de modernidad, y quizá el de jerarquía, pese a que el RD 1132/2002 cuenta con el sustento del art. 165 LGSS, conducen a la aplicación del Real Decreto-ley 5/2013, y con ello a un evidente perjuicio para el interesado por la falta de precisión normativa. El art. 3.1 del Real Decreto-ley 5/2013 establece un importe fijo de pensión del 50 por 100 «cualquiera que sea la jornada laboral o la actividad que realice el pensionista»; regla diseñada para la concurrencia con un trabajo a tiempo completo, pero que genera un notable daño para quien compatibilice la pensión con un trabajo de

50 Véase criterio de aplicación 3/2014, de 4 de marzo, de la Subdirección General de Ordenación y Asistencia Jurídica del INSS (BISS, marzo de 2014). 
jornada reducida. La jubilación flexible implica una disminución proporcional de la pensión ${ }^{51}$.

Además, la jubilación flexible contempla ventajas al recalcular la pensión de jubilación una vez que cesa la incompatibilidad, al contrario que el nuevo supuesto, ya que el art. 3.4 del Real Decreto-ley 5/2013 advierte que «finalizada la relación laboral por cuenta ajena o producido el cese en la actividad por cuenta propia, se restablecerá el percibo íntegro de la pensión de jubilación». Con todo, esa diferencia es razonable, porque la especial cotización durante este período quizá no justifique una elevación de la base reguladora y el trabajador ya disfruta de un porcentaje del 100 por 100 (presupuesto para esta especial fórmula de compatibilidad). No obstante, insistir en la exclusión del porcentaje adicional por retraso de la edad de jubilación desincentiva a los beneficiarios de retornar a la vida activa. Por cierto, la exigencia de mantenimiento de nivel de empleo que afecta a las empresas que contraten al beneficiario que compatibiliza la pensión con el trabajo (DA 1. ${ }^{a}$ del Real Decreto-ley 5/2013) no parece extrapolable a la jubilación flexible. Los notables puntos de fricción entre la jubilación flexible y el nuevo régimen de incompatibilidad exigen, cuando menos, un desarrollo reglamentario que aborde las zonas grises.

En fin, aunque no se vincule directamente a la pensión de jubilación, conviene dejar constancia que tras la Ley 27/2011 el art. 141.3 LGSS dispone que «el disfrute de la pensión de incapacidad permanente absoluta y de gran invalidez a partir de la edad de acceso a la pensión de jubilación será incompatible con el desempeño por el pensionista de un trabajo, por cuenta propia o por cuenta ajena, que determine su inclusión en alguno de los regímenes del sistema de la Seguridad Social en los mismos términos y condiciones que los regulados para la pensión de jubilación en su modalidad contributiva en el apartado 1 del art. 165 de esta Ley». La remisión al art. 165.1 LGSS plantea algunas dudas, porque si bien la compatibilidad con un trabajo a tiempo parcial parece garantizada en los términos de la jubilación flexible, no resulta clara la compatibilidad con un trabajo por cuenta propia que proporcione ingresos inferiores al SMI, por ubicarse tal previsión en el apartado 4 del art. 165. La entidad gestora considera que ese nuevo art. 141.3 LGSS implica que todas las modalidades de compatibilidad de la pensión de jubilación son igualmente aplicables en mate-

${ }^{51}$ Y. SÁnCHEZ-URÁn AZAÑA, «Trabajadores de edad avanzada (II). Compatibilidad trabajo-pensión», Actualidad Laboral, núm. 10 (2013), pp. 1271-1272, y Á. CEA AYALA, «Compatibilidad entre la pensión de jubilación y el trabajo. Breve referencia a la jubilación flexible», Actualidad Laboral, núm. 2 (2014), pp. 172 y ss. 
ria de IP absoluta y gran invalidez a partir del momento en que el beneficiario cumpla la edad ordinaria de jubilación ${ }^{52}$.

El Real Decreto-ley 5/2013 provoca otra dificultad interpretativa, toda vez que el nuevo supuesto de incompatibilidad se recoge en esa norma y no se incorpora al art. 165 LGSS. Cierto es que el art. 165.1 LGSS alude a las «salvedades y en los términos que legal o reglamentariamente se determinen», lo que permitiría una interpretación amplia mediante la cual se hiciera coincidir el régimen de incompatibilidades. Sería deseable, sin duda, mayor claridad normativa. La entidad gestora, por su parte, entiende no sólo que esta modalidad es de aplicable a la IP absoluta y a la gran invalidez, como se dijo, sino también que es imprescindible que el beneficiario reúna un período de cotización que le habría permitido disfrutar del 100 por 100 de la base reguladora de la pensión de jubilación ${ }^{53}$. Es un criterio razonable, aunque habría que entender como cotizados los años que resten desde el momento de la declaración de IP hasta el cumplimiento de la edad de jubilación, en la misma línea que el art. 140.1.b) LGSS.

\section{SUPUESTOS DE CONGELACIÓN DEL RÉGIMEN JURÍDICO}

La Ley 27/2011 y el Real Decreto-ley 5/2013 contienen dos clases de reglas transitorias. Un primer grupo se caracteriza por configurar una aplicación gradual de los nuevos y más rigurosos requisitos, como se ha desarrollado en epígrafes anteriores. El segundo grupo de reglas no se contiene en las disposiciones transitorias de esa Ley 27/2011, sino en la DF 12. ${ }^{a}$, relativa a la entrada en vigor. El apartado 2 de esa DF 12. ${ }^{a}$ precisa, en primer lugar, que la normativa previa en materia de pensión de jubilación «en sus diferentes modalidades, requisitos de acceso y condiciones y reglas de determinación de prestaciones» continuará aplicándose en determinados supuestos. Se produce de ese modo una congelación del régimen jurídico precedente para determinadas situaciones, lo que permite que ese endurecimiento de requisitos no afecte a las personas que puedan disfrutar de esta especial ventaja. Ahora bien, pese a la congelación de régimen jurídico será posible la aplicación del beneficio por cuidado de hijos antes aludido, por

\footnotetext{
52 Véase ampliación de 4 de abril de 2014, de la Subdirección General de Ordenación y Asistencia Jurídica del INSS, del criterio de aplicación 5/2010 (BISS, abril de 2014).

${ }^{3}$ Ibid.
} 
cuanto tal beneficio no se ubica entre las «modalidades, requisitos de acceso y condiciones y reglas de determinación de prestaciones».

La congelación de régimen jurídico cuenta con un horizonte temporal definido, pero de notable amplitud, pues la legislación vigente antes de 1 de enero de 2013 podrá continuar siendo de aplicación a las pensiones de jubilación que se causen antes de 1 de enero de 2019. De este modo, la edad de jubilación ordinaria permanecerá en sesenta y cinco años, la base reguladora se calculará conforme a las cotizaciones de los quince años anteriores al hecho causante, no se utilizará el nuevo procedimiento de integración de lagunas, los porcentajes aplicables a la base reguladora (tanto el ordinario como los aparejados al retraso de la edad de jubilación) permanecerán inalterados y los requisitos de la jubilación anticipada y parcial serán menos rigurosos. En cualquier caso, no surge un derecho de opción, de modo que se aplicará la regulación anterior aunque pudiera resultar menos beneficiosa para el interesado; supuesto excepcional, aunque en hipótesis pudiera ocurrir en materia de jubilación anticipada por el cambio de parámetro temporal entre años y trimestres, por ejemplo. Obviamente, estas reglas especiales no amparan las cláusulas convencionales de extinción del contrato por razón de edad, tradicionalmente contempladas en la DA $10{ }^{a}$ ET, ya que, por más que fueran conocidas como cláusulas de «jubilación forzosa», técnicamente no podían considerarse como una modalidad de pensión de jubilación.

El primero de los supuestos de congelación de régimen jurídico está concebido para las personas cuya relación laboral —o vínculo administrativo como funcionario interino o personal estatutario temporal ${ }^{54}$ «se haya extinguido antes de 1 de abril de 2013, siempre que con posterioridad a tal fecha no vuelvan a quedar incluidas en alguno de los regímenes del sistema de la Seguridad Social». Aunque la redacción pudiera resultar técnicamente deficiente, porque la extinción del contrato de trabajo no supone automáticamente la exclusión de un régimen del sistema (el trabajador podrá permanecer comprendido en el mismo en situación asimilada al alta, inclusive mediante la suscripción de un convenio especial ${ }^{55}$ ), parece claro que el legislador se refiere al trabajador que, tras la extinción de su contrato de trabajo, no encuentra un nuevo empleo. La causa de extin-

54 Véase ampliación de 10 de enero de 2014, de la Subdirección General de Ordenación y Asistencia Jurídica del INSS, del criterio de aplicación 22/2000 (BISS, enero de 2014).

55 Véase ampliación de 9 de septiembre de 2014, de la Subdirección General de Ordenación y Asistencia Jurídica del INSS, del criterio de aplicación 22/2000 (BISS, septiembre de 2014). 
ción del contrato de trabajo parece irrelevante y se concreta que este beneficio se limita a los trabajadores asalariados.

El segundo supuesto de congelación del régimen jurídico afecta a «las personas con relación laboral suspendida o extinguida como consecuencia de decisiones adoptadas en expedientes de regulación de empleo o por medio de convenios colectivos de cualquier ámbito, acuerdos colectivos de empresa, así como por decisiones adoptadas en procedimientos concursales aprobados, suscritos o declarados con anterioridad a 1 de abril de 2013, siempre que la extinción o suspensión de la relación laboral se produzca con anterioridad a 1 de enero de 2019». El precepto suscita alguna duda interpretativa, como, por ejemplo, la posible ultraactividad de la jubilación especial a los sesenta y cuatro años para trabajadores con relación laboral suspendida en las empresas afectadas por estas decisiones. La DD Única de la Ley 27/2011 derogó el RD 1194/1985, de 17 de julio, y, por tanto, dejó sin amparo normativo las cláusulas convencionales o acuerdos con los propios trabajadores en los que se previese esta modalidad. No obstante, la congelación de régimen jurídico por esta vía permitiría defender su subsistencia.

Por otro lado, el precepto no aclara si pueden disfrutar de esa congelación de régimen jurídico los trabajadores afectados por ese proceso de reestructuración si encuentran otro empleo. Es probable que la intención del legislador fuera contraria a esa posibilidad y que, por tanto, esta ventaja se concibiera para trabajadores inactivos, como se deduce del tenor literal del precepto («personas con relación laboral suspendida o extinguida»). Sin embargo, la norma no resulta todo lo precisa que sería deseable, y ante situaciones de reanudación de la actividad laboral intermitentes o de muy corta duración no es descartable que, por el perjuicio que supone de ordinario la aplicación de la nueva regulación, los tribunales se decanten por admitir la congelación de régimen jurídico también en esos supuestos.

Finalmente, se contempla la congelación de régimen jurídico en materia de jubilación parcial. En concreto, la letra $c$ ) del apartado 2 de esa DF 12. ${ }^{a}$ de la Ley 27/2011 contiene dos reglas específicas en materia de jubilación parcial. La primera de ellas, en la redacción previa a la reforma de 2013, remitía a la normativa precedente a «quienes hayan accedido a la pensión de jubilación parcial con anterioridad a la fecha de publicación de la presente Ley». La precisión resulta de interés porque no se atendía a la fecha de entrada en vigor, sino de la publicación, y los dieciséis meses de vacatio legis se convertían en un elemento determinante. En consecuencia, la Ley 27/2011 disponía que a partir de 1 de enero de 2013 
las jubilaciones parciales producidas antes de 2 de agosto de 2011 conservarían su régimen jurídico. En cambio, las jubilaciones parciales que tuvieron lugar desde 2 de agosto en adelante se verían afectadas — a partir de 1 de enero de 2013 - por la reforma legal, y, concretamente, habrían de respetar la correspondencia entre las bases de cotización del jubilado parcial y del relevista, así como la regla de elevación paulatina de la base de cotización del jubilado parcial prevista en la DT 22. ${ }^{a}$ LGSS.

La segunda de las reglas transitorias obedecía al propósito de respetar los compromisos previos en materia de jubilación parcial. Con esa finalidad se establecía la congelación de régimen jurídico para «las personas incorporadas antes de la fecha de publicación de esta Ley a planes de jubilación parcial recogidos en convenios colectivos de cualquier ámbito o acuerdos colectivos de empresas, con independencia de que el acceso a la jubilación parcial se haya producido con anterioridad o posterioridad al 1 de enero de 2013». Es ésta una regla, por lo demás, diseñada a medida para determinados sectores, principalmente el automóvil, pues ciertas inversiones en España parecen depender de que se respeten esta clase de acuerdos.

El Real Decreto-ley 29/2012 impidió que estas previsiones fueran realmente de aplicación el 1 de enero de 2013, ya que, como se ha reiterado, suspendió durante tres meses la entrada en vigor de esas reglas a la espera de la aprobación de un nuevo régimen jurídico de la jubilación parcial y de la jubilación anticipada que tuvo lugar con el Real Decreto-ley 5/2013. $\mathrm{El}$ art. 8 de esta norma da nueva redacción al apartado 2 de la DF 12. ${ }^{a}$ de la Ley 27/2011, para consolidar las excepciones ya indicadas hasta el año 2019.

Concretamente, se congela el régimen jurídico hasta el 1 de enero de 2019 para «quienes hayan accedido a la pensión de jubilación parcial con anterioridad al 1 de abril de 2013» (cambio notable respecto de la regla nonnata que remitía a la fecha de publicación de la Ley 27/2011), así como para «las personas incorporadas antes de dicha fecha a planes de jubilación parcial recogidos en convenios colectivos de cualquier ámbito o acuerdos colectivos de empresa con independencia de que el acceso a la jubilación parcial se haya producido con anterioridad o posterioridad al 1 de abril de 2013». A estos efectos, mantienen efectos los planes de jubilación parcial vigentes en el momento de una transmisión de empresas, a salvo de que tras esa operación se haya negociado en otro sentido ${ }^{56}$. No es imprescindible que se trate de compromisos en sentido estricto, pues

56 Véase ampliación de 10 de marzo de 2014, de la Subdirección General de Ordenación y Asistencia Jurídica del INSS, del criterio de aplicación 22/2000 (BISS, marzo de 2014). 
se han admitido planes de jubilación parcial sin la obligación empresarial de aceptar la pretensión del trabajador ${ }^{57}$. La congelación de régimen jurídico no sólo afectará a la jubilación parcial, sino en su caso a la jubilación completa posterior, siempre que el hecho causante se produzca antes del 1 de enero de 2019 y que el trabajador efectivamente haya accedido a la jubilación parcial, pues no será suficiente la mera inclusión en convenios o acuerdos que contengan compromisos de jubilación parcial ${ }^{58}$.

Conviene precisar que el art. 4 del RD 1716/2012 (modificado por la DF 5.a del Real Decreto-ley 5/2013) regula el procedimiento que debió seguirse para comunicar los convenios o acuerdos colectivos - no siendo aptos a tal fin los acuerdos individuales o plurales - ${ }^{59}$ a la entidad gestora antes de 15 de abril de 2013; trámite insubsanable, pues el documento presentado con posterioridad suele ser calificado como simulación ${ }^{60}$. Nótese que el Real Decreto-ley 5/2013 entró en vigor el 17 de marzo de 2013 y admite la congelación de régimen jurídico para acuerdos celebrados antes del 1 de abril de 2013. Las disposiciones transitorias no se diseñan, por lo general, para atender supuestos de hecho aún no existentes en el momento de entrada en vigor de la norma, con lo que el fin último de esa regla es, como se advirtió, no dificultar ciertos procesos de reestructuración empresarial que, a corto o medio plazo, podrían ser beneficiosos para el mercado de trabajo español. Con todo, conceder un plazo tras la entrada en vigor de la norma para celebrar tales acuerdos parece, cuando menos, poco ortodoxo.

En fin, pese a la multiplicidad de reglas transitorias no resulta claro si esta congelación del régimen jurídico alcanza, asimismo, a las novedosas reglas de compatibilidad entre pensión y trabajo introducidas por el Real Decreto-ley 5/2013. En principio, esa congelación afecta a las «diferentes modalidades, requisitos de acceso y condiciones y reglas de determinación» de la pensión de jubilación. La compatibilidad entre pensión y trabajo no da lugar a una nueva «modalidad» de pensión —ni siquiera la jubilación flexible es una modalidad en sentido técnico-, y la congelación de régimen jurídico parece diseñada para mantener inalterados los requisitos de

57 Véase STSJ de Castilla y León (Valladolid) de 28 de mayo de 2014 (recurso 613/2014).

58 Y. SÁNCHEZ-URÁn AZAÑA, «Trabajadores de edad avanzada (I). Jubilación anticipada y jubilación parcial», Actualidad Laboral, núm. 9 (2013), pp. 1124 y ss., y M. A. PÉrEZ ALONSo, «Cuestiones prácticas y divergencias en la pensión de jubilación tras las últimas reformas», RGDTSS, núm. 35 (2013).

59 Véase SSTSJ de Asturias de 19 de septiembre de 2014 (recurso 1549/2014) y del País Vasco de 17 de junio de 2014 (recurso 996/2014).

60 Véase STSJ del País Vasco de 17 de junio de 2014 (recurso 998/2014). 
acceso y la forma de cálculo de la pensión, respetando expectativas de personas próximas al retiro, y no para facilitar el retorno al trabajo de los ya jubilados. Desde esta perspectiva, la referencia a «condiciones y reglas de determinación» se vincularía a los cambios en materia de base reguladora y porcentajes aplicables, y, por tanto, a la determinación inicial de la pensión. En conclusión, la congelación de régimen jurídico no afecta a las reglas de compatibilidad entre la pensión de jubilación y el trabajo, de modo que el nuevo régimen jurídico introducido por el Real Decreto-ley 5/2013 resulta plenamente operativo desde el 17 de marzo de 2013.

\section{LA IMPLEMENTACIÓN DEL FACTOR DE SOSTENIBILIDAD}

Las incertidumbres sobre la viabilidad del sistema de Seguridad Social han llevado a muchos países europeos a adoptar reformas que garanticen la pervivencia de los sistemas de pensiones cuando comiencen a acceder a la jubilación quienes forman parte de la llamada generación del baby boom. La elevación de la edad de jubilación, el incremento del número de años necesarios para alcanzar el 100 por 100 de la base reguladora, las modificaciones en el modo de calcular la base reguladora o el endurecimiento de los requisitos para acceder a la jubilación anticipada son muestras de ese propósito. No obstante, esas reformas suponen un coste político y social importante en el momento de su adopción, y, quizás por ello, se han buscado fórmulas de adaptación automática de los sistemas de pensiones que no requieran continuas reformas legales. Los sistemas de pensiones, en cierta forma, adoptarían una configuración flexible, más viva, y se adaptarían a la evolución de los distintos índices demográficos y económicos con el fin de ir adecuando la intensidad de su acción protectora a las disponibilidades económicas en cada momento.

Esa nueva fisonomía se consigue a través de la introducción de lo que se ha dado en llamar «factor de sostenibilidad», expresión de contenido difuso y que puede concretarse en formulaciones muy distintas. En primer lugar, ese factor de sostenibilidad puede vincular la edad ordinaria de jubilación a la esperanza de vida, de modo que la edad ordinaria se modifique automáticamente para adecuarse a la esperanza de vida de cada momento. De este modo, si el objetivo, por ejemplo, consiste en fijar una edad de jubilación que diste quince años de la esperanza de vida a medida que ésta aumente, así se incrementará la edad de jubilación. En segundo lugar, 
ese factor de sostenibilidad puede vincular la esperanza de vida al período mínimo de carencia (no necesariamente de la jubilación ordinaria, sino también de la anticipada), de forma que se exija un mayor período cotizado cuanto mayor sea la esperanza de vida. Y en tercer lugar, ese factor de sostenibilidad puede afectar al importe de la pensión, con el propósito de garantizar que el incremento de la esperanza de vida no suponga unas cargas cualitativamente mayores para el erario público. Aunque las posibilidades en esta última vía son múltiples, a modo estrictamente ejemplificativo, el mecanismo podría asemejarse al siguiente: se efectúa un cálculo del capital coste de la pensión de jubilación en el momento del hecho causante y posteriormente se divide esa cantidad entre el número de años previstos de cobro; cuanta mayor sea la esperanza de vida, menor será la cuantía de la pensión, aunque en cómputo global la cantidad sería la misma. De este modo, no hay una única configuración del factor de sostenibilidad, sino múltiples posibilidades, y a buen seguro se requerirán ajustes constantes en función de la experiencia propia y de la de los países del entorno.

En España, el art. 8 de la Ley 27/2011 introdujo una DA 59. ${ }^{a}$ en la LGSS cuyo tenor literal es el siguiente: «Con el objetivo de mantener la proporcionalidad entre las contribuciones al sistema y las prestaciones esperadas del mismo y garantizar su sostenibilidad, a partir de 2027 los parámetros fundamentales del sistema se revisarán por las diferencias entre la evolución de la esperanza de vida a los sesenta y siete años de la población en el año en que se efectúe la revisión y la esperanza de vida a los sesenta y siete años en 2027. Dichas revisiones se efectuarán cada cinco años, utilizando a este fin las previsiones realizadas por los organismos oficiales competentes». Las consecuencias de la crisis económica, y fundamentalmente las presiones externas, motivaron un adelanto de esta previsión temporal, pues el Acuerdo del Consejo de Ministros de 12 de abril de 2013 encargó a un comité de expertos la elaboración de un «Informe sobre el factor de sostenibilidad del sistema público de pensiones» (informe que se emitiría el 7 de junio de 2013) ${ }^{61}$.

Las propuestas recogidas en ese informe incidían, especialmente, en la cuantía de la pensión de jubilación y no en la edad de acceso o en el período de carencia. El «factor de sostenibilidad» propuesto se concretaba, por un lado, en el denominado «Factor de Equidad Intergeneracional» (FEI) y, por otro, en el «Factor de Revalorización Anual» (FRA), cuya imple-

${ }^{61}$ Véase http://www1.seg-social.es/ActivaInternet/groups/public/documents/rev_anexo/ rev_032187.pdf. 
mentación, a tenor del informe, habría de producirse entre 2014 y 2019 (pp. 23-24). El Factor de Equidad Intergeneracional «busca que las condiciones de las pensiones sean iguales para todos los jubilados, con independencia de la cohorte demográfica a la que pertenezcan». El propósito, como antes se advirtió, consiste en conseguir que los beneficiarios en situaciones equivalentes de edad y cotización perciban un importe similar de pensión en términos globales, aunque el hecho causante se actualice con años de diferencia, lo que supone, por consiguiente, una disminución de la pensión inicial de aquellos que pertenecen a generaciones con mayor esperanza de vida, a los que se aplicará un coeficiente corrector. Dicho de otro modo, en la medida en que cada año aumenta la esperanza de vida, las pensiones iniciales se reducirán, si bien el efecto no resultará demasiado drástico, porque la elevación anual de la esperanza de vida no es muy significativa y por ello los efectos sobre la cuantía de la pensión únicamente adquirirán relevancia a largo plazo.

El informe no precisaba qué datos sobre esperanza de vida habrán de tomarse, y en particular si se tendrían en consideración las diferencias por sexo. Aunque no es previsible que en España se proceda a una diferenciación, la introducción de un factor de sostenibilidad en la que se conecten los mecanismos correctores con la esperanza de vida podría llegar a propiciar, eventualmente, que ese factor de sostenibilidad afectase a las mujeres de forma más gravosa que a los varones, pues estadísticamente su esperanza de vida es mayor. No sería, desde luego, una situación desconocida o inédita, pues algún país de nuestro entorno ha introducido factores actuariales de corrección del importe de las prestaciones de Seguridad Social atendiendo a la esperanza de vida de hombres y mujeres. El TJUE ha considerado que este tipo de fórmulas resultan discriminatorias por razón de sexo, ya que «la toma en consideración de datos estadísticos generales según el sexo choca con la inexistencia de certeza acerca de que una asegurada tenga siempre una esperanza de vida superior a la de un asegurado de la misma edad que se halla en una situación comparable» ${ }^{62}$.

Por su parte, el Factor de Revalorización Anual debería introducir, a partir de la pensión media, «una corrección basada en la relación entre ingresos y gastos del sistema de pensiones» (p. 6), de modo que se desliga la revalorización del IPC y la cuantía podrá incrementarse o reducirse en función del «crecimiento de los ingresos, del número de pensiones, del efecto sustitución (derivado de que los pensionistas que entran anualmen-

${ }^{62}$ Cfr. STJUE X de 3 de septiembre de 2014 (asunto C-318/13). 
te en el sistema lo hacen con pensiones distintas de los que salen), así como de la diferencia entre ingresos y gastos del sistema de pensiones» (p. 13). No obstante, se sugiere evitar los posibles efectos indeseados de este índice respecto de quienes ya sean beneficiarios de la pensión en el momento de su implantación mediante el establecimiento de una «cláusula suelo» que impida la disminución nominal de la pensión (p. 8). El informe hacía especial hincapié en cálculos a medio y largo plazo para afrontar las dificultades de ciclos económicos negativos (p. 13).

La plasmación práctica de las propuestas de ese informe del comité de expertos tuvo lugar con la Ley 23/2013, de 23 de diciembre, reguladora del Factor de Sostenibilidad y del Índice de Revalorización del Sistema de Pensiones de la Seguridad Social. Por consiguiente, el Factor de Sostenibilidad se identifica exclusivamente con el Factor de Equidad Intergeneracional diseñado en el informe. Conviene asimismo poner de manifiesto la incidencia de la LO 2/2012, de 27 de abril, de Estabilidad Presupuestaria y Sostenibilidad Financiera, dictada al amparo del reformado art. 135 CE, cuyo art. 18.3 contemplaba la aprobación de una ley en la que se regulasen «los mecanismos de revalorización y ajuste que resulten necesarios para garantizar el equilibrio presupuestario y la sostenibilidad financiera del sistema de Seguridad Social».

Esa norma fue la citada Ley 23/2013, que anticipa la aplicación del factor de sostenibilidad en ocho años en relación con la previsión inicial. En efecto, la Ley 27/2011, como se dijo, contemplaba 2027 como momento inicial para poner en marcha este factor de sostenibilidad. Tras la Ley 23/2013 ese factor comenzará a operar para las pensiones causadas a partir del 1 de enero de 2019, con el objetivo declarado de ajustar el importe global de la pensión a la esperanza de vida.

El cálculo de ese factor de sostenibilidad implica realizar operaciones complejas y hasta opacas, pues la fórmula recogida en el art. 4 de la Ley es ciertamente poco asequible:

$\mathrm{FS}_{\mathrm{t}}=\mathrm{FS}_{\mathrm{t}-1} * \mathrm{e}_{67}^{*}$

donde:

FS $=$ Factor de sostenibilidad .

$\mathrm{FS}_{2018}=1$.

$\mathrm{t}=$ Año de aplicación del factor, que tomará valores desde el año 2019 en adelante.

$\mathrm{e}_{67}^{*}=$ Valor que se calcula cada cinco años y que representa la variación interanual, en un período quinquenal, de la esperanza de vida a los sesenta 
y siete años, obtenida ésta según las tablas de mortalidad de la población pensionista de jubilación del sistema de la Seguridad Social.

En cualquier caso, con los datos actuales ya puede calcularse el factor de sostenibilidad para el primer quinquenio (en el quinquenio 2024-2028 el factor de sostenibilidad se calculará tomando la esperanza de vida 2017-2022):

\begin{tabular}{|c|c|}
\hline Año & Factor de sostenibilidad \\
\hline 2019 & 0,9953 \\
\hline 2020 & 0,9906 \\
\hline 2021 & 0,9860 \\
\hline 2022 & 0,9813 \\
\hline 2023 & 0,9767 \\
\hline
\end{tabular}

Por consiguiente, quienes causen pensión en 2019 no recibirán el montante total que correspondería a la aplicación a la base reguladora del porcentaje aplicable en atención al tiempo de cotización, minorado en caso de jubilación anticipada. Una vez realizadas todas esas operaciones es necesario aplicar el factor de sostenibilidad, que implica una reducción de la pensión. Detrás de esta fórmula subyace, en cierto modo, una concepción que apuesta más por la capitalización que por el reparto ${ }^{63}$. No en vano, los términos que se utilizan para la comparación son dos pensiones causadas en momentos temporales distintos por personas con carreras de seguro similares. Se entiende que el hecho de haber nacido (o haber vivido, o haberse jubilado) en un contexto distinto donde la esperanza de vida es mayor no puede suponer que en cómputo global la cuantía de la pensión de jubilación sea ventajosa. Dicho de otro modo, una vez determinado el importe de la pensión de jubilación (mensual o anual) se calcula una suerte de capital-coste, con lo que se determina el importe total estimado de pensión que percibirá hasta su fallecimiento una persona. Esa cantidad global vincula a quienes accedan a la pensión en el futuro en condiciones equivalentes, porque es la cuantía global que ellos también recibirán, pero al disfrutar de una mayor esperanza de vida habrá de repartirse ese dinero entre los años que restan para su estimado fallecimiento, y por ello la cuantía mensual a recibir es menor, aunque globalmente perciban la misma cantidad.

${ }^{63}$ C. Gala Durán, «Un nuevo modelo de pensión de jubilación: el impacto del índice de revalorización anual y del factor de sostenibilidad», Iuslabor, núm. 1 (2014) (bttp://www. raco.cat/index.php/IUSLabor/article/view/274202/362287). 
Es un procedimiento imaginativo, sin duda, aunque técnicamente debiera ser perfilado. Más allá de cuestionar la introducción de una técnica tan asociada a la capitalización en un sistema como el español, que se basa generalmente en otros principios, resulta paradójico - e incluso cuestionable a partir del art. $14 \mathrm{CE}$ - que no se explique con claridad por qué el mismo mecanismo no opera en relación con otras pensiones vitalicias, como la IP o la viudedad, máxime cuando las pensiones de IP cambian su denominación y ciertos rasgos de su régimen jurídico (como la incompatibilidad con el trabajo) cuando el beneficiario alcanza la edad ordinaria de jubilación.

Además, el diseño de este factor de corrección requeriría de cierta adaptación antes de su implementación práctica, porque parte de presunciones iuris et de iure que dan lugar a resultados desproporcionados. En particular, sorprende que la aplicación del factor de corrección no tome en consideración ni la edad del pensionista en el momento de la jubilación ni la modalidad de jubilación, sino que asume que el beneficiario causa la pensión de jubilación ordinaria a la edad legal. Esa homogeneización no es en absoluto aceptable, porque el factor de sostenibilidad asume que el beneficiario percibirá la pensión durante un tiempo dado, en atención a la esperanza de vida de su generación, pero tanto en supuestos de jubilación anticipada como de jubilación postergada el beneficiario pertenece a otra generación y su tiempo de disfrute estimado de la pensión no puede ser idéntico al de personas con una edad distinta. Podría argüirse que el legislador ha eludido conscientemente esos matices, que podrían conducir a una doble penalización de quien se jubila anticipadamente o a un doble beneficio - aunque la dulcificación del factor de corrección por atender a la edad real difícilmente puede considerarse un beneficio- de quien accede a la jubilación postergada, pero en el caso de jubilación parcial no existen esas correcciones de cuantía, y aun así parece que el factor de corrección toma en consideración la edad en la que se causa la jubilación parcial, o al menos así parece desprenderse del art. 2 de la Ley («el factor de sostenibilidad se aplicará, en los términos establecidos en esta Ley, por una sola vez para la determinación del importe inicial de las nuevas pensiones de jubilación del sistema de la Seguridad Social»). Es curioso, asimismo, que en un contexto en el que trata de potenciarse el retraso de la edad de jubilación, la decisión del interesado de jubilarse a una edad superior a la legal pueda perjudicarle, ya que le será de aplicación el factor de sostenibilidad pensado para generaciones posteriores a la suya, mini- 
mizando el impacto del coeficiente de incremento de pensión por retraso de la edad de jubilación.

En fin, la Ley 23/2013 también introduce el Índice de Revalorización, si bien en este punto no puede olvidarse el significativo precedente del Real Decreto-ley 28/2012, de 30 de noviembre, de Medidas de Consolidación y Garantía del Sistema de la Seguridad Social, que procedió a suspender el art. 48 LGSS con el fin de desligar la revalorización del IPC, estableciendo un incremento fijo del 1 por 100. La Ley 23/2013 establece un procedimiento más sofisticado que toma en cuenta los ingresos y los gastos del sistema, y que, en todo caso, no puede dar lugar a un valor negativo, pues se establece una garantía mínima de incremento de las pensiones del 0,25 por 100 .

Se trata de medidas que desde luego pueden implicar un cambio en el modelo tradicional y suponen sin duda una minoración de la cuantía de las pensiones, y por ello admiten críticas desde una perspectiva política, ideológica o social ${ }^{64}$. No obstante, el reproche jurídico es más complejo ${ }^{65}$, porque recurrir al principio de suficiencia de las prestaciones del art. $41 \mathrm{CE}$ o a la exigencia de actualización periódica de las pensiones del art. $50 \mathrm{CE}$ o del art. 65.10 del Convenio OIT exige demasiado esfuerzo argumentativo, en buena medida voluntarista. Cuestión distinta es que la técnica jurí-

${ }^{64}$ J. L. Tortuero Plaza, «Ley 23/2013, de 23 de diciembre, reguladora del factor de sostenibilidad y del índice de revalorización del sistema de pensiones de la Seguridad Social: régimen jurídico», Relaciones Laborales, núm. 5 (2014), pp. 109 y ss.; J. L. MONEREO PÉReZ, «Factor de sostenibilidad e índice de revalorización: estado de la cuestión», Aranzadi Social, vol. 6, núm. 8 (2013), pp. 99 y ss.; M. Rodríguez-PiñERo y Bravo-Ferrer y M. E. Casas BaAMONDE, «El factor de sostenibilidad de las pensiones de jubilación y la garantía de la suficiencia económica de los ciudadanos durante la tercera edad», Relaciones Laborales, núm. 5 (2014), pp. 1 y ss.; S. GonZÁlez ORTEGA, «El nuevo régimen de revalorización de las pensiones», Relaciones Laborales, núm. 5 (2014), pp. 145 y ss.; B. SuÁrez CORUJO, «El factor de sostenibilidad: ¿el caballo de Troya del sistema público de pensiones?», Temas Laborales, núm. 121 (2013), pp. 22 y ss.; J. López GANDíA, «La dimensión constitucional de la reforma de las pensiones», Relaciones Laborales, núm. 5 (2014), pp. 20 y ss.; C. AraGón GÓMEZ, «Otra vuelta de tuerca a la reducción de la cuantía de las pensiones», Revista de Información Laboral, núm. 1 (2014), pp. 29 y ss.; E. TerRadillos OrmaeChEA, «La regulación del factor de sostenibilidad y del índice de revaloración del sistema de pensiones de la Seguridad Social a la luz de la entrada en vigor del protocolo facultativo del pacto internacional de derechos económicos, sociales y culturales», RGDTSS, núm. 36 (2014); D. TosCANI GIMÉNEZ, «Revalorización de las pensiones en la Ley 23/2013, de 23 de diciembre, y su posible constitucionalidad», Relaciones Laborales, núm. 2 (2014), pp. 91 y ss., y E. GuERRERO VizUeTE, «La deconstrucción del sistema público de pensiones a través de la Ley 23/2013, de 23 de diciembre, reguladora del factor de sostenibilidad», REDT, núm. 165 (2014), pp. 89 y ss.

${ }^{6}$ A. Desdentado Bonete, «Reflexiones sobre el factor de sostenibilidad del sistema público de pensiones», Documentación Laboral, núm. 99 (2013), pp. 16-18. 
dica sea deficiente en muchas ocasiones y que no se aprecie con claridad la justificación de recurrir a fórmulas matemáticas tan sumamente complejas, prácticamente incompresibles, que en la práctica provocarán que la prevista «aplicación transparente» (DA 1. ${ }^{a}$ de la Ley 23/2013) resulte una quimera. En cualquier caso, las opciones políticas, por más que socialmente perjudiciales, no son per se inconstitucionales y seguramente no es el plano jurídico el vehículo más apropiado para el reproche.

\section{CONSIDERACIONES FINALES}

La necesidad de acometer reformas en el sistema de pensiones con el fin de garantizar su sostenibilidad se sustenta en proyecciones económico-demográficas bien conocidas y difícilmente rebatibles. No obstante, las concretas medidas a adoptar y el momento y el modo que deban implementarse es susceptible de discusión, pues las opciones son varias y podrían llegar a implicar, en su caso, un cambio de modelo a partir de una apuesta - mayor o menor- por la capitalización. Es claro que la configuración del sistema de pensiones depende de cada sociedad y del modo en que se han ido construyendo los mecanismos de protección social. En buena medida, el sistema de pensiones forma parte de la idiosincrasia de un país, de sus tradiciones y valores, y por ello las modificaciones de gran calado generan un importante rechazo social.

De ahí que no resulte extraño que la reforma 2011-2013 no ponga en cuestión explícitamente la pervivencia del sistema de reparto ni abogue, por tanto, por un cambio de modelo. El objetivo consiste en introducir las modulaciones necesarias para que el sistema de pensiones pueda seguir operando conforme a sus principios clásicos, aunque adaptados a un nuevo contexto. Es claro, no obstante, que en el futuro se producirá un desequilibrio entre ingresos y gastos motivado por un importante incremento de los gastos y una disminución de los ingresos. Siempre desde ese propósito de mantener inalterados los rasgos básicos del sistema, los remedios pasan por incrementar los ingresos, reducir los gastos o combinar ambas fórmulas. Desde luego, cualesquiera medidas generan oposición social, porque el aumento de los ingresos implica incrementar las cargas impositivas, directas o indirectas, mientras que la reducción de gastos conlleva el endurecimiento de los requisitos de acceso a las prestaciones y una menor generosidad en el cálculo de su cuantía. 
Las decisiones legislativas provocan, sin duda, efectos colaterales (por ejemplo, sobre la previsión privada) que sólo se potenciará cuando los ciudadanos perciban la necesidad real de acudir a ella. Y esa necesidad está vinculada a una disminución de la tasa de reemplazo de la pensión de jubilación, de manera que el importe de la pensión sea significativamente más reducido que el salario que se percibía en activo. Cuanto más apueste el legislador por vías de incremento de ingresos, menos imprescindible será la previsión complementaria.

Sea cual sea la opción futura, no parece que el legislador incurra en riesgo real de inconstitucionalidad, al menos a partir de la flexible interpretación que la jurisprudencia constitucional ha efectuado del art. $41 \mathrm{CE}$, que establece unos requisitos e impone ciertas tendencias, pero la normativa infraconstitucional no se ha encontrado con ceñidos corsés, toda vez que la Seguridad Social es «un derecho de estricta configuración legal» ${ }^{66}$. No obstante, resulta deseable que las medidas introducidas respeten determinados límites vinculados con la idoneidad, la necesidad y, especialmente, la proporcionalidad. Es claro, como se dijo, que la viabilidad futura requiere de la adopción de ciertas reformas. También lo es que la situación actual de crisis económica ha acelerado la toma de decisiones. Pero en materia de Seguridad Social debe actuarse con extremada prudencia y no confundir lo coyuntural con lo estructural. Dicho en otros términos, las situaciones coyunturales requieren de medidas coyunturales, de modo tal que las medidas estructurales deben reservarse para hacer frente a problemas estructurales, pues de lo contrario podría entenderse vulnerado el principio de igualdad en virtud de la desproporción de la medida adoptada, como puso de manifiesto el TC portugués en su Sentencia de 5 de julio de 2012, si bien en relación con la supresión de las pagas extraordinarias ${ }^{67}$.

Esa prudencia, o valoración sosegada, debería prevalecer en la actuación legislativa, evitando la aprobación de normas por impulso y no suficientemente meditadas. Esta conclusión, válida con carácter general, es mucho más relevante en un ámbito como el de la Seguridad Social, que exige cierta estabilidad para un adecuado funcionamiento y un correcto análisis. Resulta significativo que las reformas legales contemplen una aplicación gradual mediante largos períodos transitorios que se consideran imprescindibles por varios motivos y que en un breve tiempo desde su adopción se ponga en cuestión esa aplicación gradual, o directamente se

\footnotetext{
${ }^{66}$ Cfr. STC 37/1994, de 10 de febrero.

67 Véase http://www.tribunalconstitucional.pt/tc/acordaos/20120353.html.
} 
suprima, como ocurrió con el Real Decreto-ley 8/2010 en relación con la reforma operada por la Ley $40 / 2007^{68}$.

Parece evidente que la reforma de 2011-2013 no es definitiva, y ni siquiera la introducción del factor de sostenibilidad evitará que antes de 2027, fecha prevista para que esa reforma se aplique en su integridad, se cuestione la configuración misma del sistema. Sea como fuere, debe prestarse especial atención a la situación de las personas que se encuentran próximas a la edad de jubilación, porque no sólo les afectará la reforma de 2011-2013, sino también el nuevo factor de sostenibilidad y los cambios que parecen avecinarse en un futuro próximo, lo que potencialmente les sitúa en una posición comprometida en la que pueden sufrir perjuicios proporcionalmente mayores que otros colectivos ante el juego combinado de todas esas reglas.

En último término, el legislador parece decidido a respetar completamente los derechos de quienes ya han accedido a la pensión de jubilación, de modo que el sacrificio lo asumirían íntegramente los trabajadores en activo que se conviertan en nuevos beneficiarios. La eventual consideración del importe de la pensión como un derecho adquirido y la calificación de la medida como una expropiación ilícita ${ }^{69}$ podrían constituir una garantía para los actuales pensionistas, aunque desde luego en este ámbito entran en juego otros argumentos que permiten poner en cuestión esa doctrina, porque la naturaleza jurídica de la pensión es distinta a la del salario. Una vez que el servicio se presta el trabajador adquiere el derecho al salario, y el impago deriva en un enriquecimiento injusto del empleador; en cambio, el pensionista no genera derechos por el mero transcurso del tiempo, y difícilmente cabe considerar que medidas dirigidas a favorecer la viabilidad de un mecanismo de solidaridad intergeneracional como la Seguridad Social den lugar a un enriquecimiento injusto. A la postre, si el sistema de pensiones deriva inviable y no puede afrontar sus obligaciones de pago, los pensionistas también se verán perjudicados, todos ellos, porque no cabe defender que los más antiguos cuenten con una preferencia de pago sobre los más modernos. La fecha de acceso a la pensión no supone un mejor derecho de cobro. Por consiguiente, cualquier medida dirigida a mejorar la viabilidad del sistema podría afectar lícitamente también a los actuales pensionistas y no sólo a los nuevos beneficiarios. Cuestión distinta es que razones de conveniencia u oportunidad pudieran aconsejar un trato distinto.

${ }_{68}$ G. BARRIOS BAUdor, «Actualización del sistema de Seguridad Social (III): la reforma de la jubilación», Aranzadi Social, vol. 4, núm. 8 (2011), pp. 11 y ss.

${ }_{69}$ Véase AATC 85/2011, de 7 de junio, y 179/2011, de 13 de diciembre, y STS de 28 de noviembre de 2012 (recurso 143/2011), entre muchas otras. 